\title{
Resisting state terror : theorizing communities of activist translators and interpreters
}

Link to publication record in Manchester Research Explorer

\section{Citation for published version (APA):}

Baker, M., Bielsa, E. (Ed.), \& Hughes, C. W. (Ed.) (2009). Resisting state terror : theorizing communities of activist translators and interpreters. In Globalisation, Political Violence and Translation (pp. 222-242). Palgrave Macmillan Ltd. http://www.palgrave.com/products/title.aspx?pid=307155

\section{Published in:}

Globalisation, Political Violence and Translation

\section{Citing this paper}

Please note that where the full-text provided on Manchester Research Explorer is the Author Accepted Manuscript or Proof version this may differ from the final Published version. If citing, it is advised that you check and use the publisher's definitive version.

\section{General rights}

Copyright and moral rights for the publications made accessible in the Research Explorer are retained by the authors and/or other copyright owners and it is a condition of accessing publications that users recognise and abide by the legal requirements associated with these rights.

\section{Takedown policy}

If you believe that this document breaches copyright please refer to the University of Manchester's Takedown Procedures [http://man.ac.uk/04Y6Bo] or contact uml.scholarlycommunications@manchester.ac.uk providing relevant details, so we can investigate your claim.

\section{OPEN ACCESS}




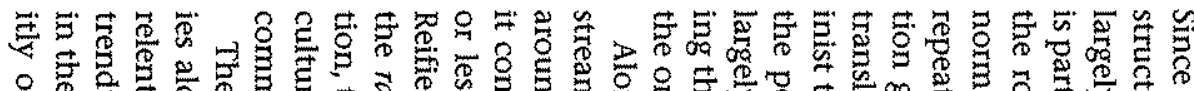

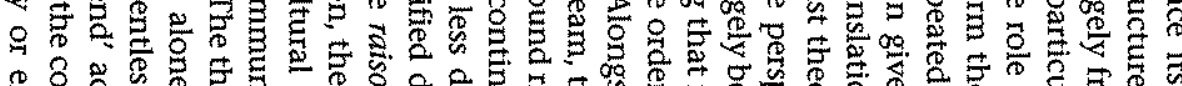

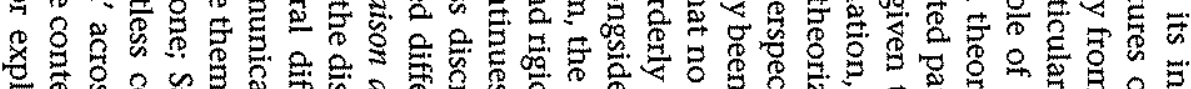

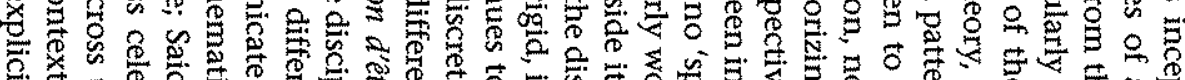

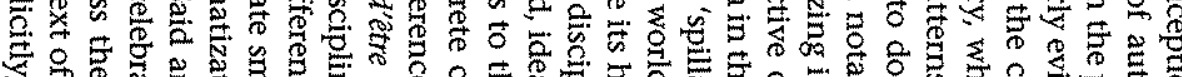

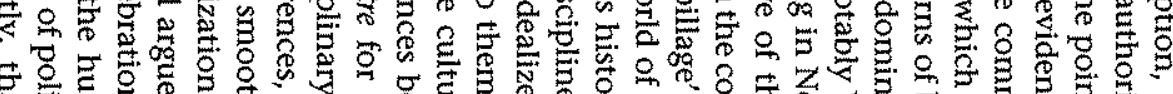

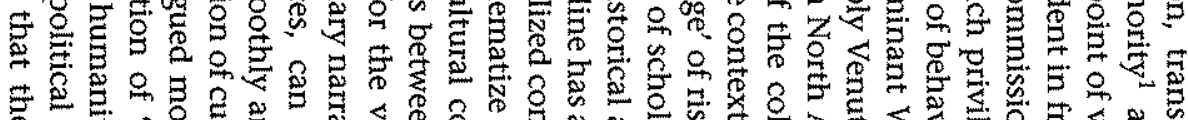

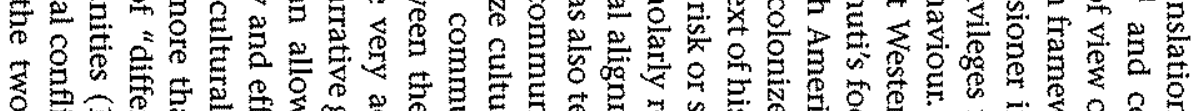

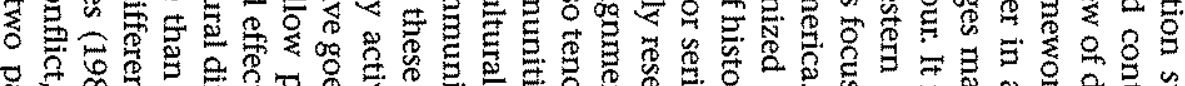

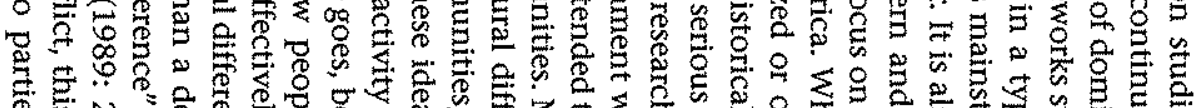
N N

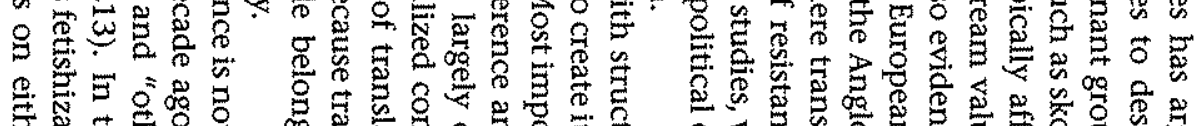

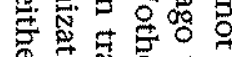

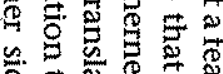

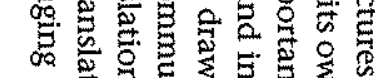

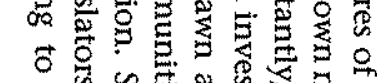

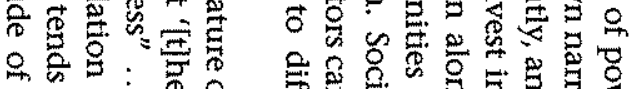
际:

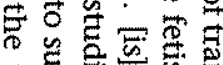

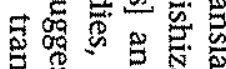

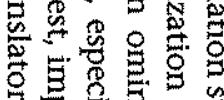

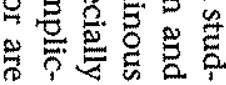

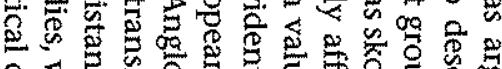

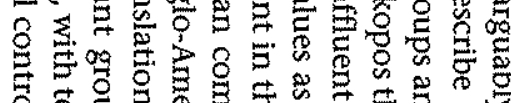

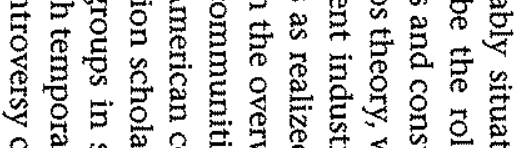

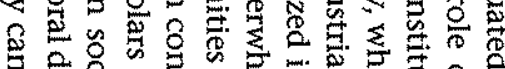

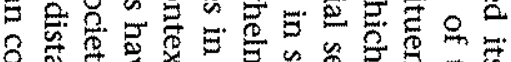

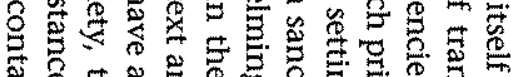

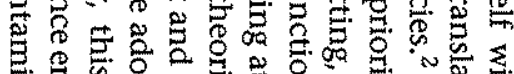

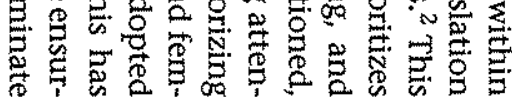

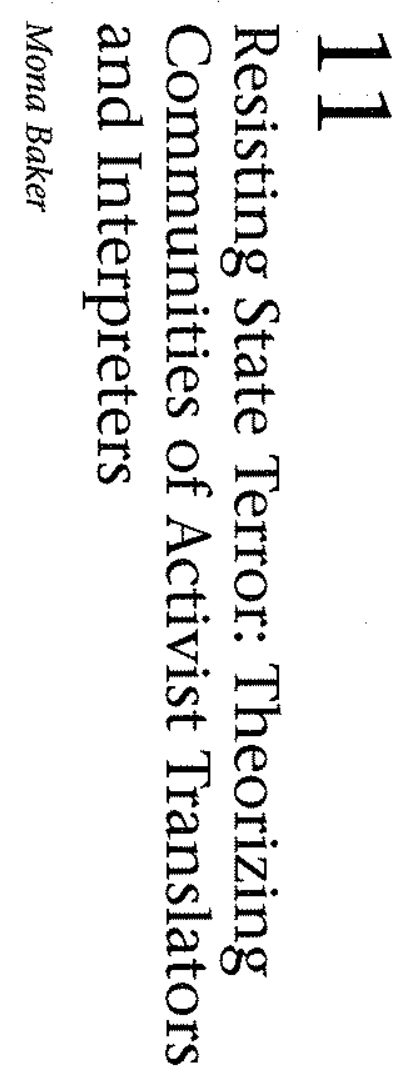

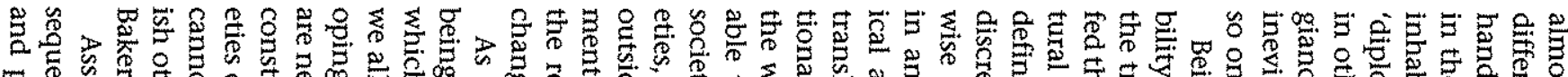

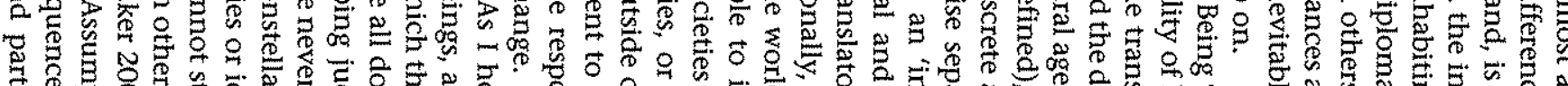

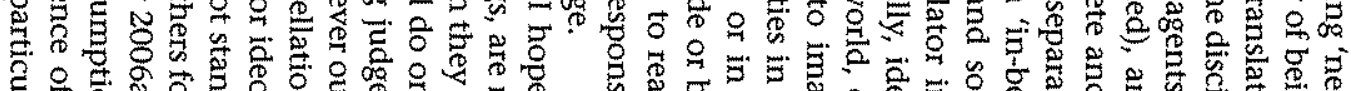

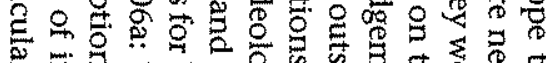

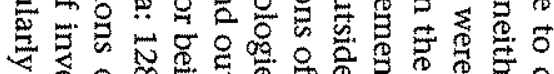

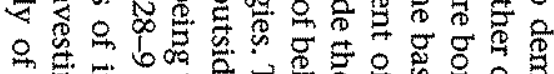

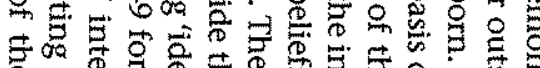

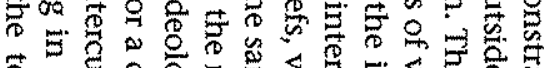

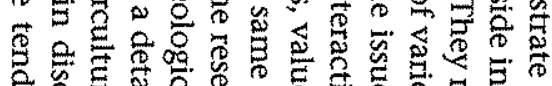

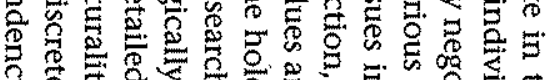

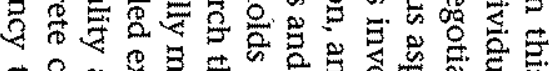

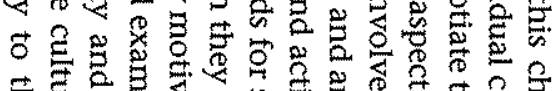

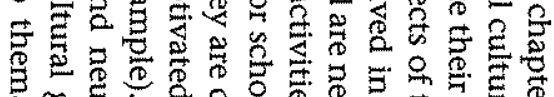

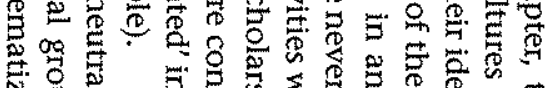

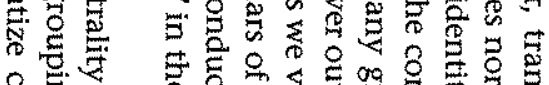

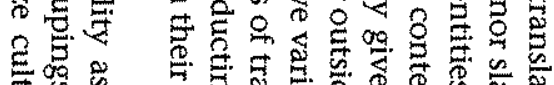

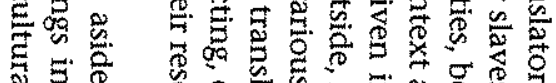

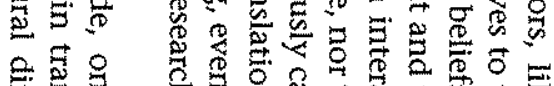

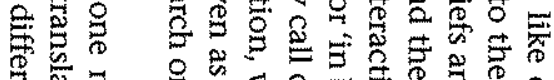

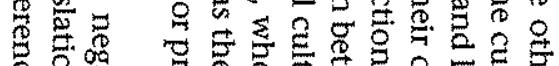

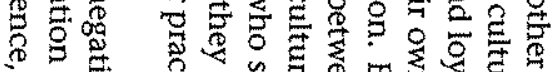

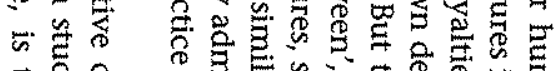

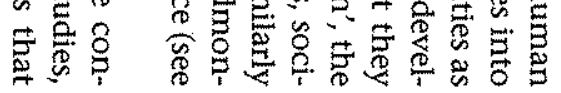

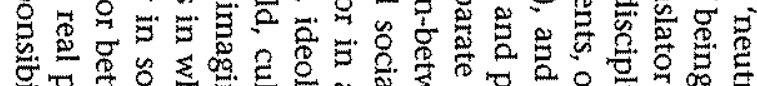

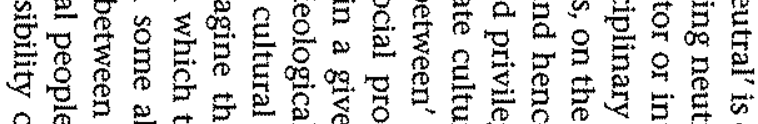

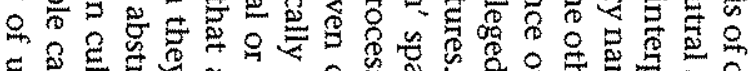
E.

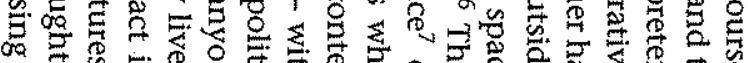

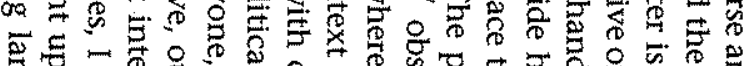

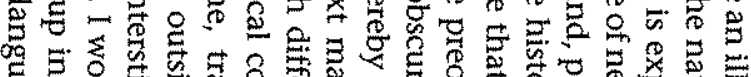

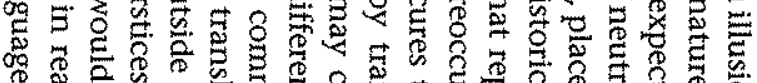

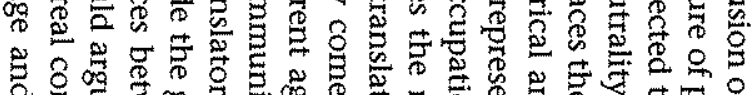

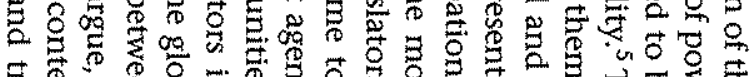

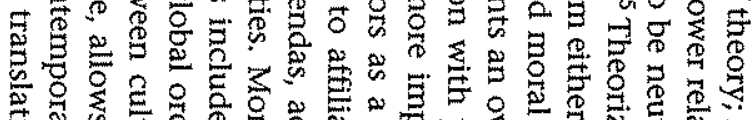

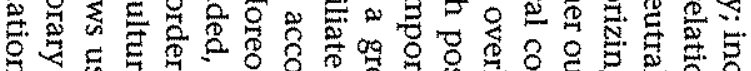

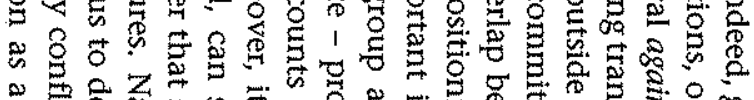

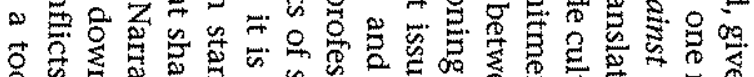

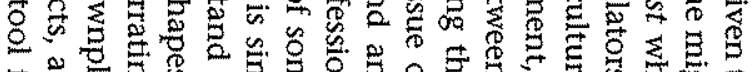

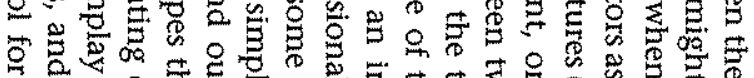

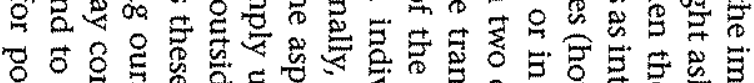

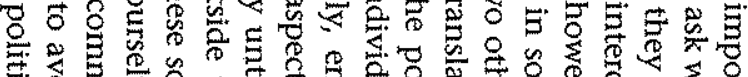

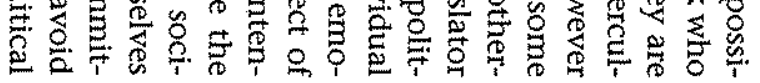

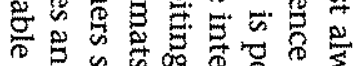

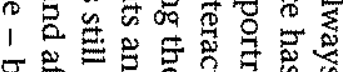

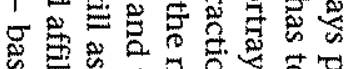

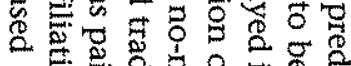

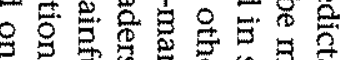

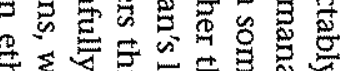

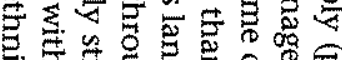

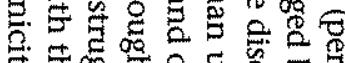

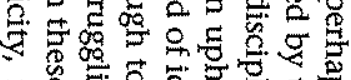

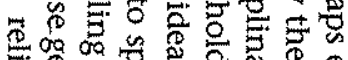

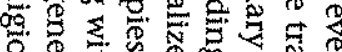

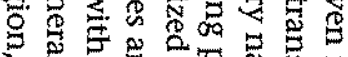

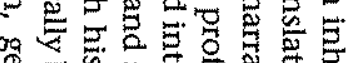

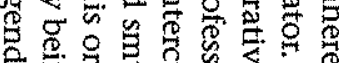

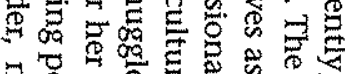

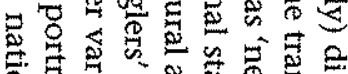

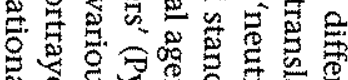

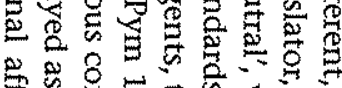

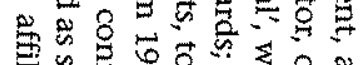

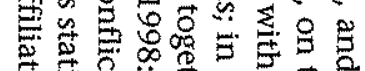

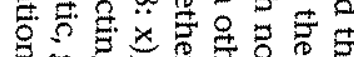
gog o

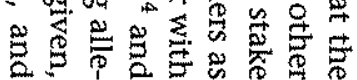




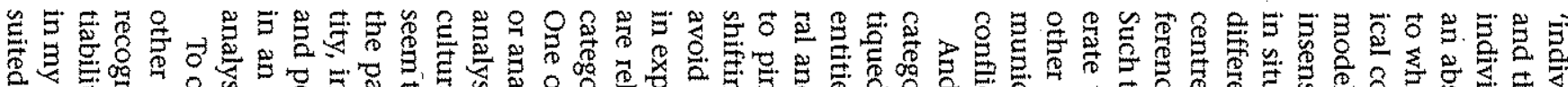
运胞.

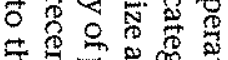

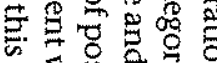

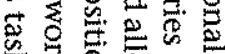

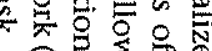

蓲

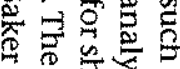

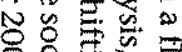

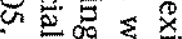

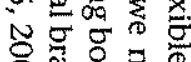

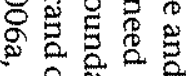

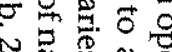

용

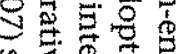

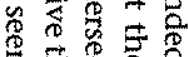
眾 둘 象

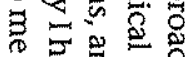

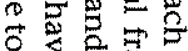

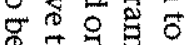

需.

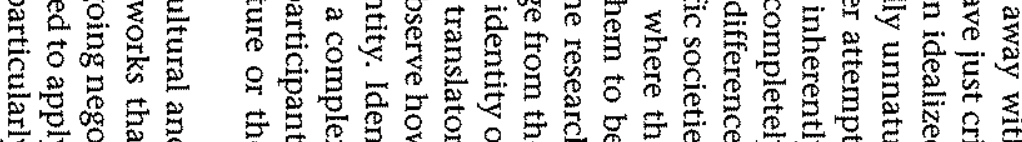

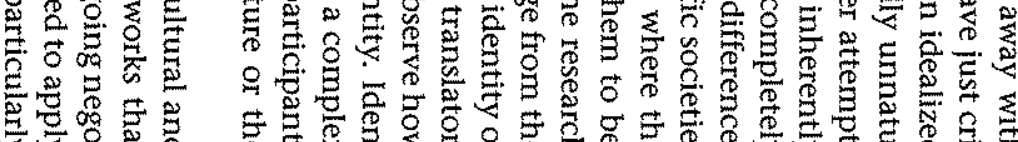

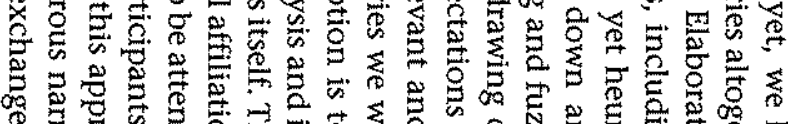

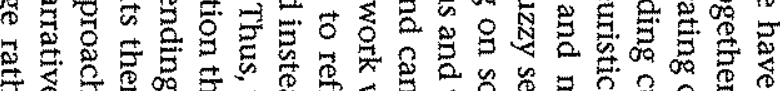

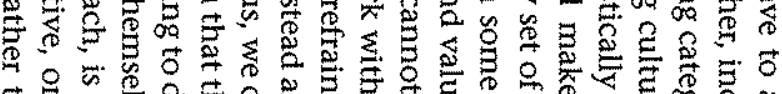

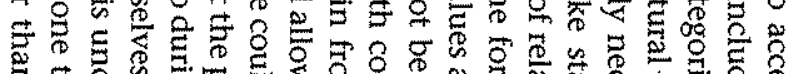

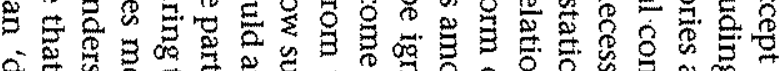

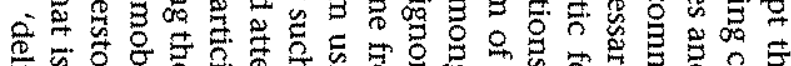

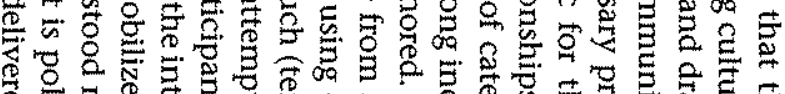

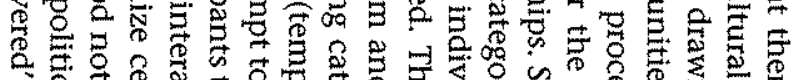

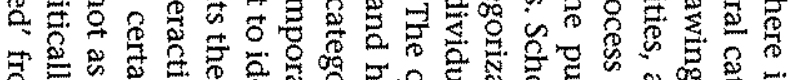

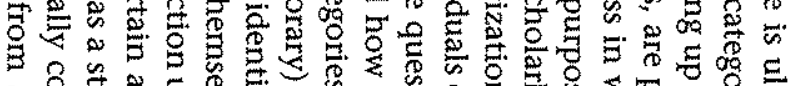

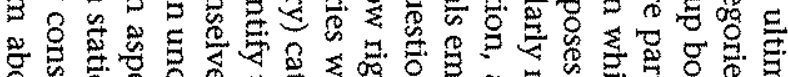

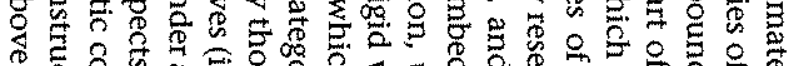

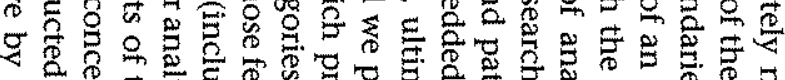

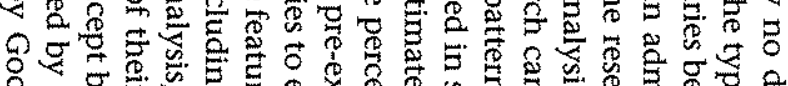

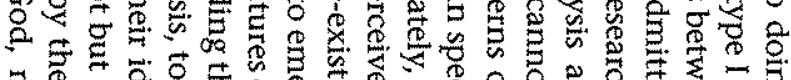

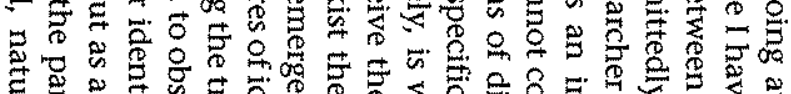

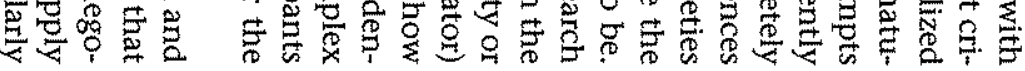

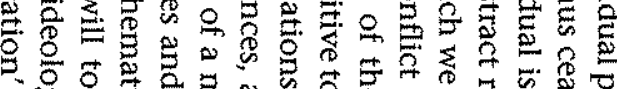

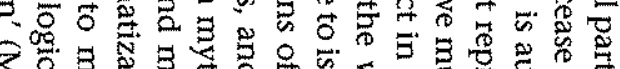

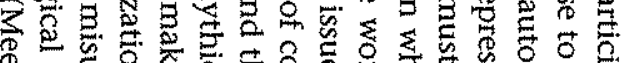

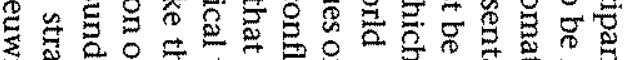

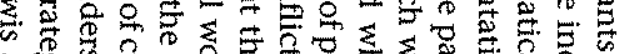

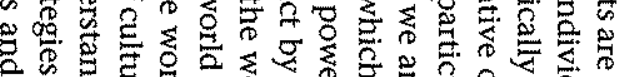

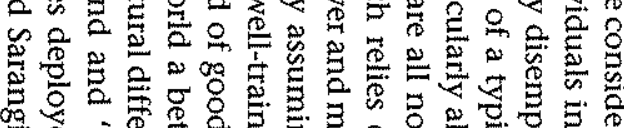

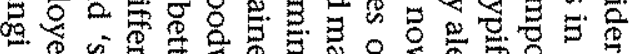

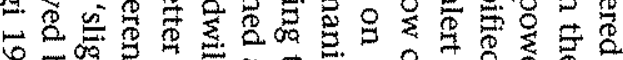

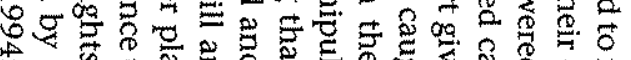

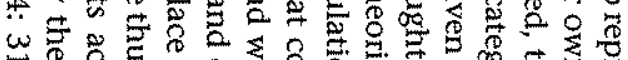

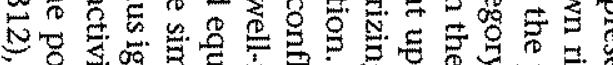

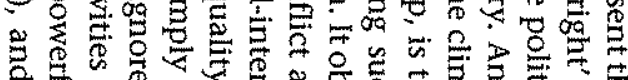

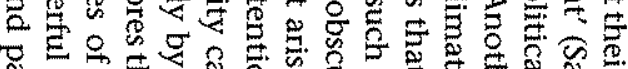

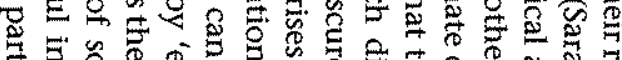

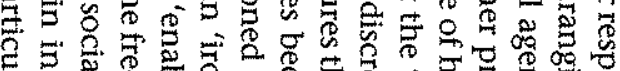

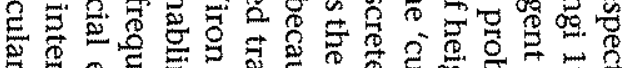

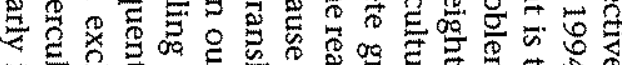

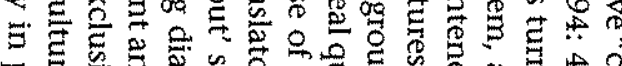

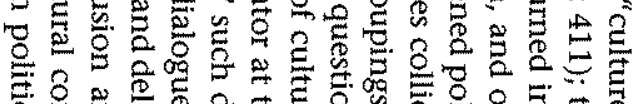

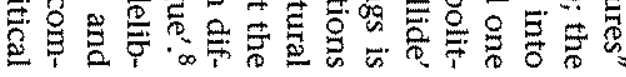

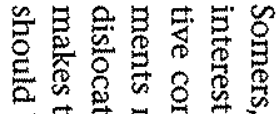

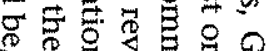

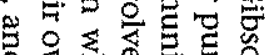

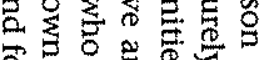
要

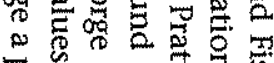

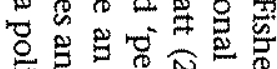

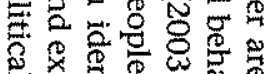
象司出

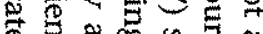

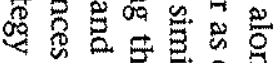
क 0 舟

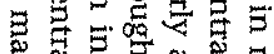

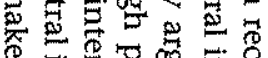

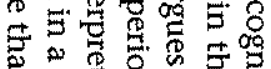
。

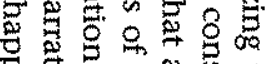

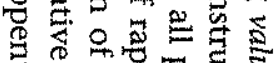
可证要

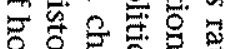

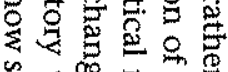

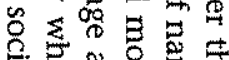

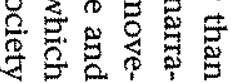

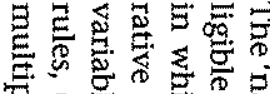

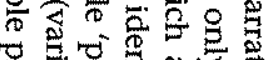

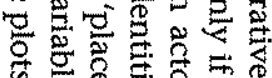
象里需

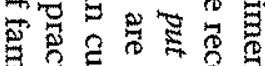
要奂.

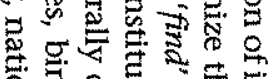

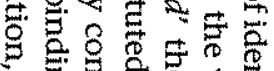

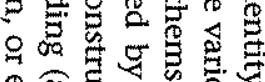

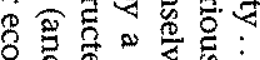

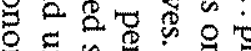

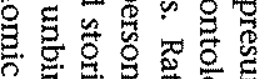

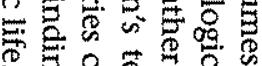

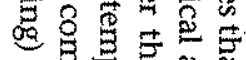

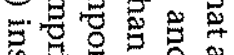

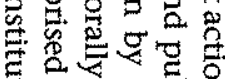

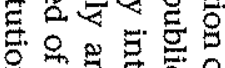

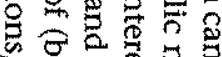

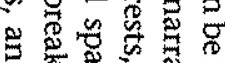

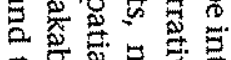

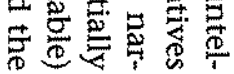

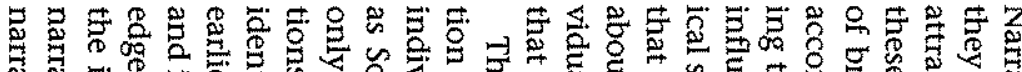

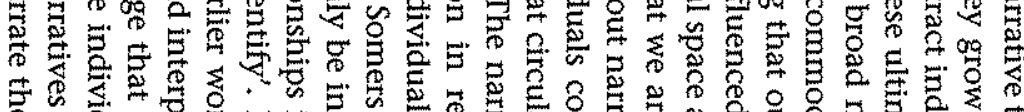

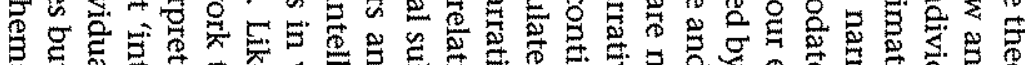

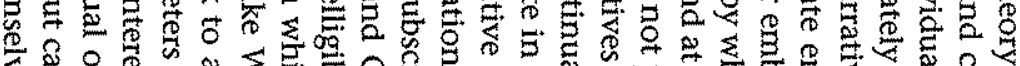

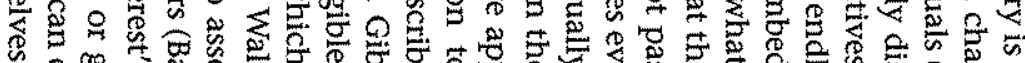

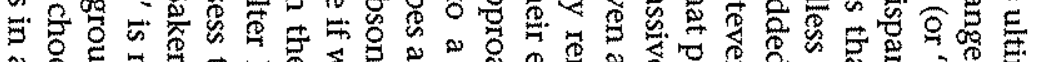

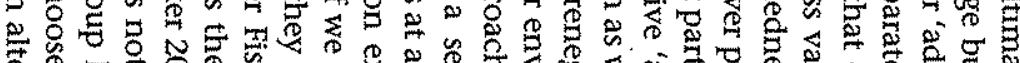

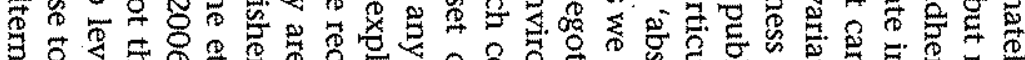

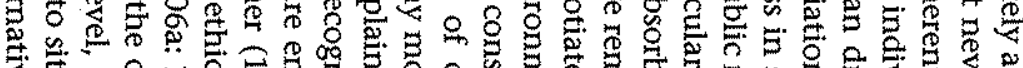

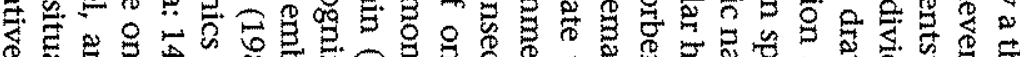

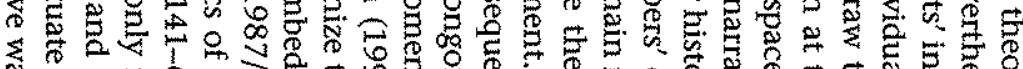

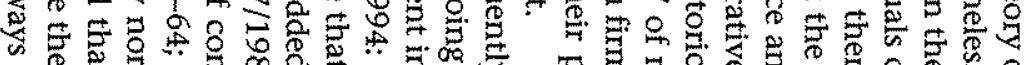

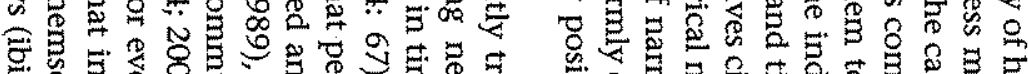

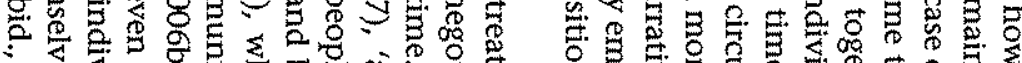

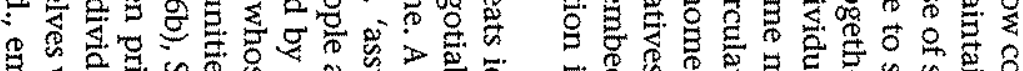

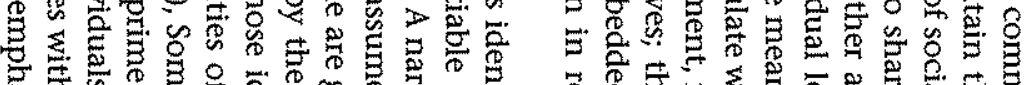

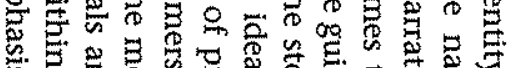

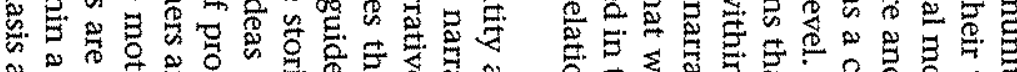

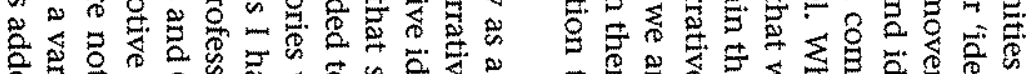

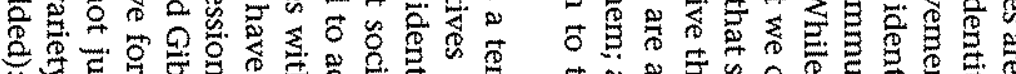

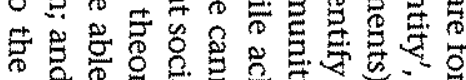

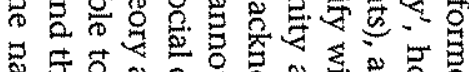

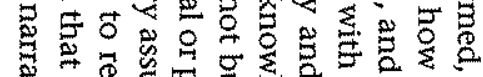

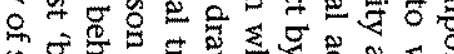

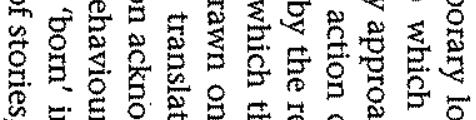

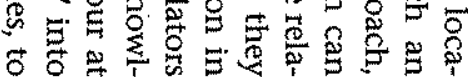




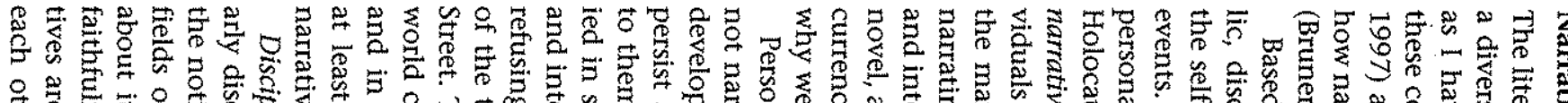

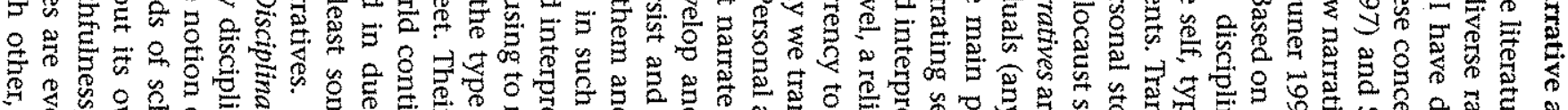

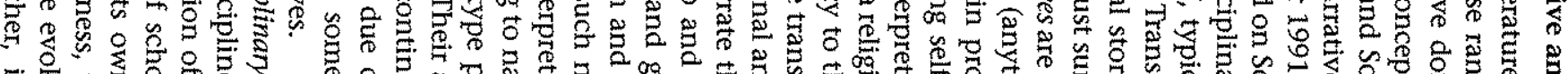

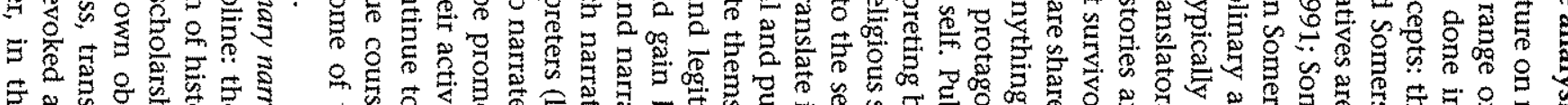

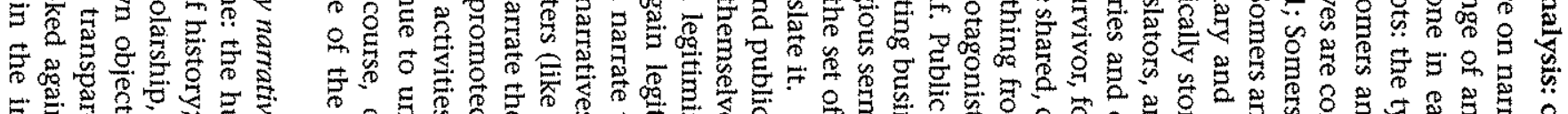

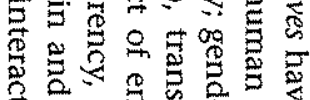
每

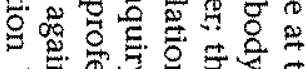
II

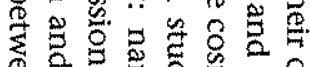
B 政

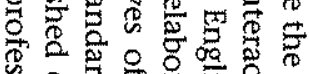

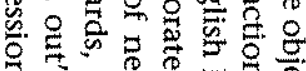

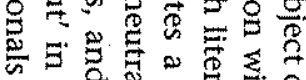

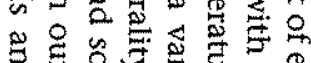

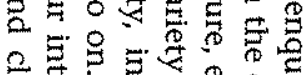

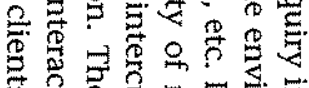

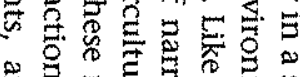

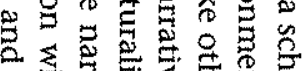

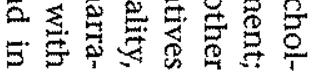

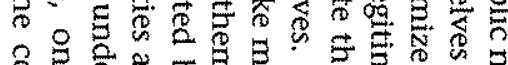

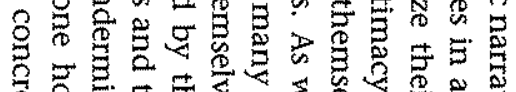

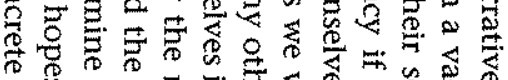

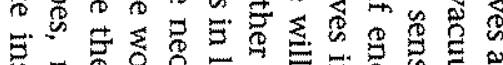

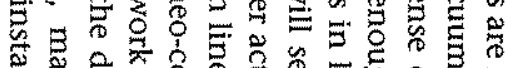

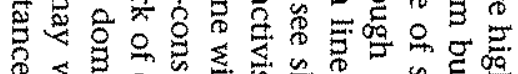

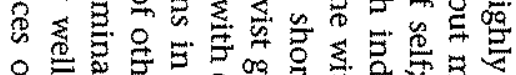

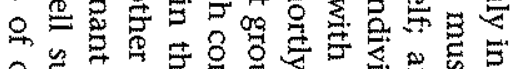

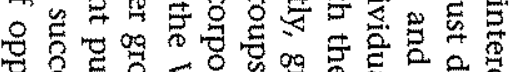

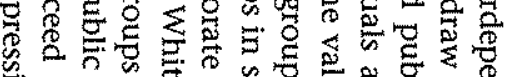

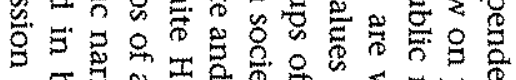

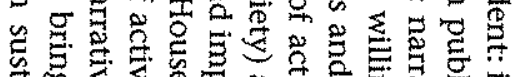

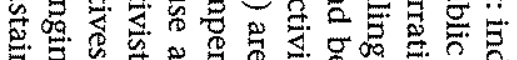

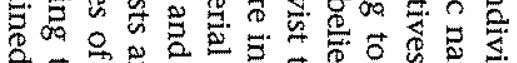

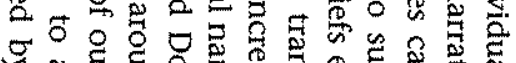

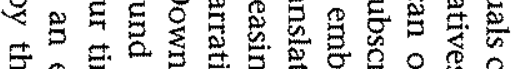

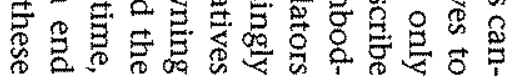

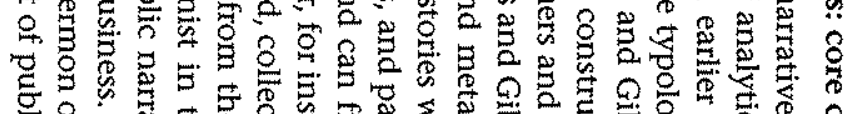

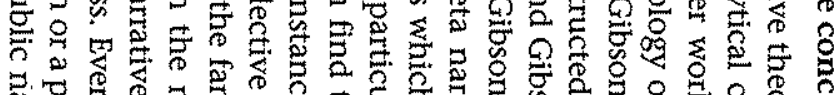

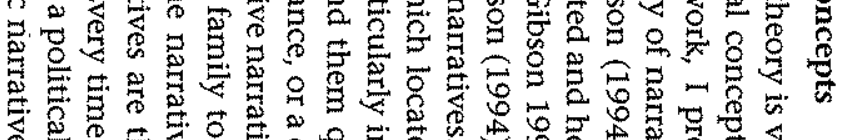

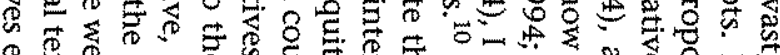

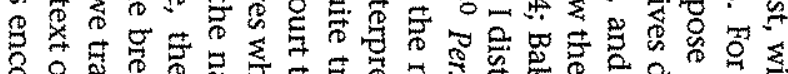

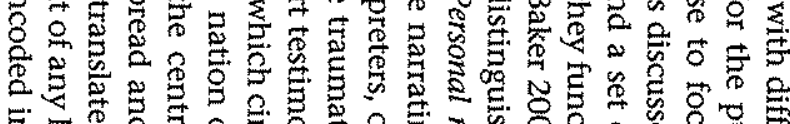

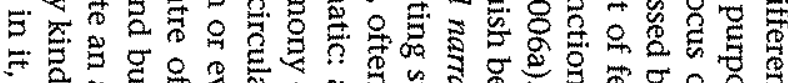

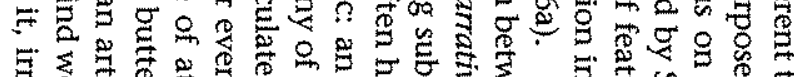

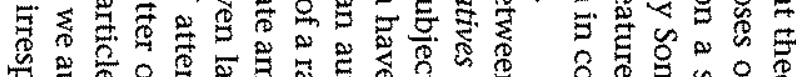

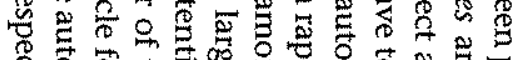

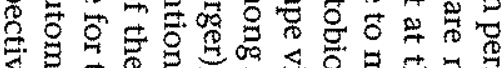

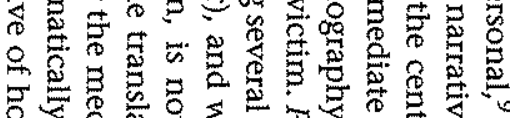

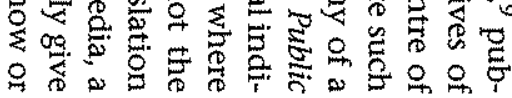

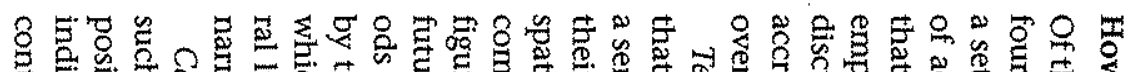

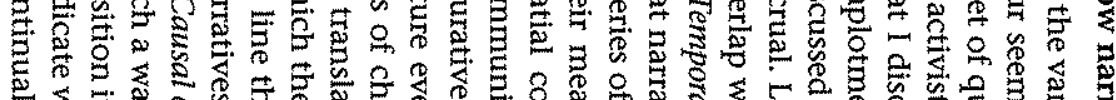

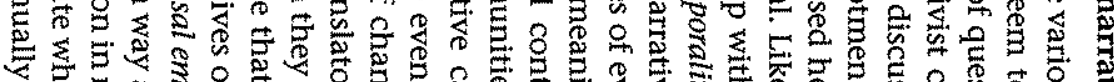

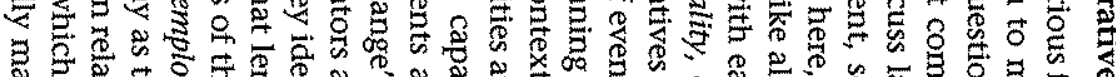

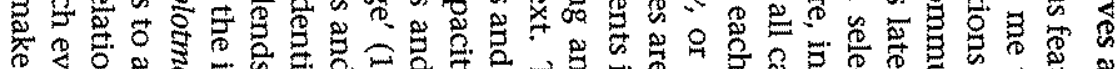

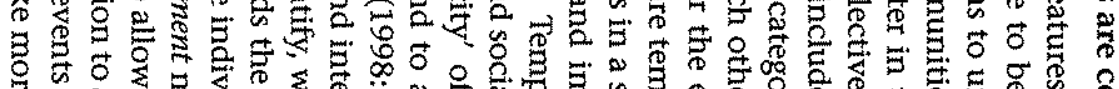

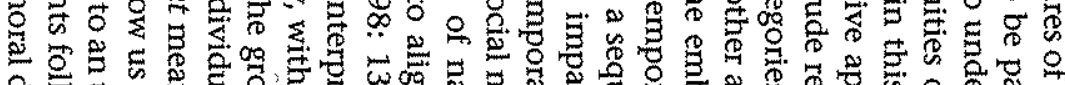

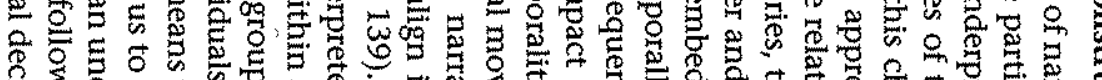

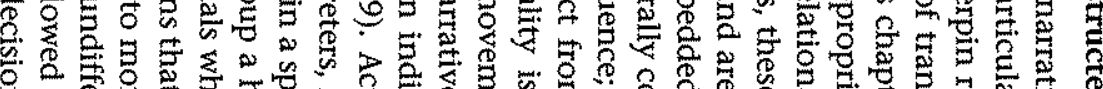

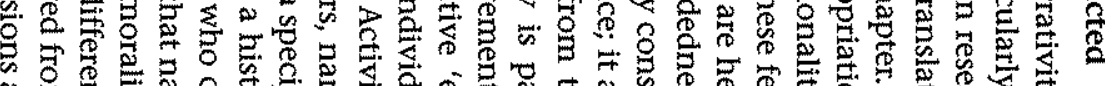

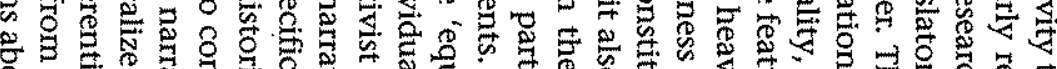

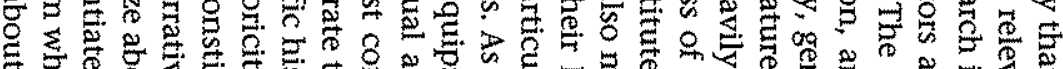

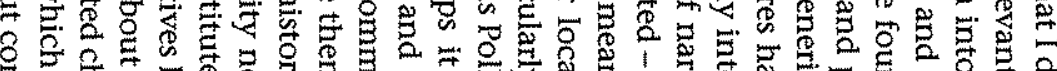

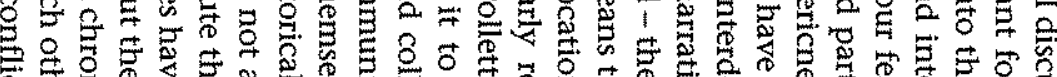

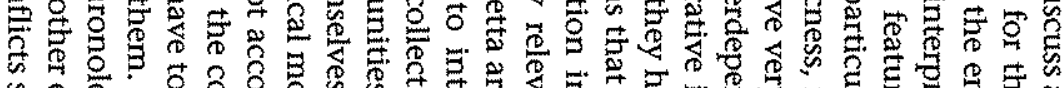

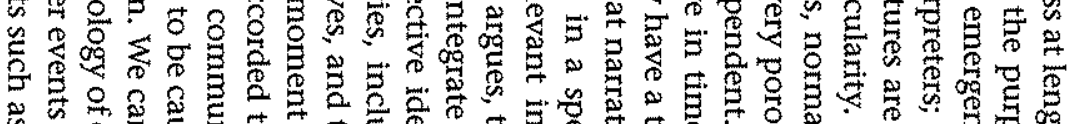
心

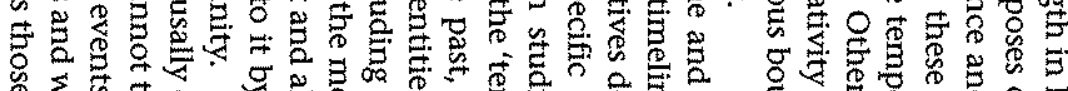

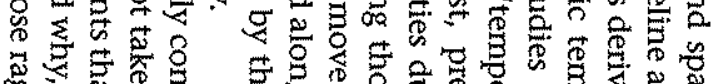

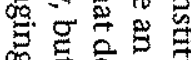

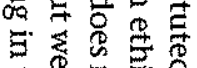

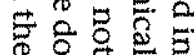

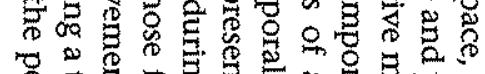

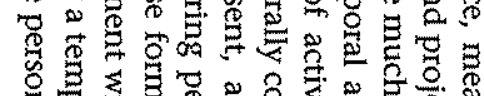

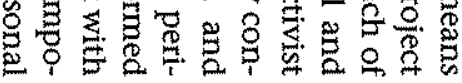

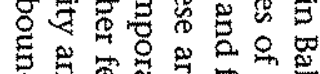

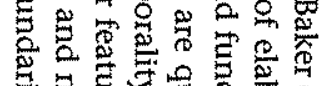

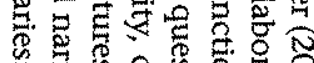

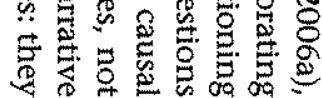

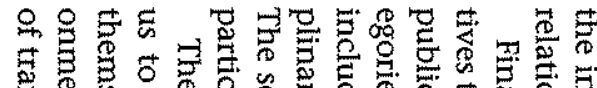

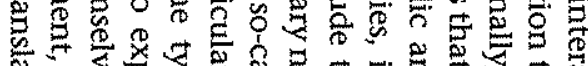

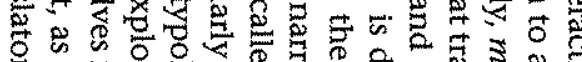

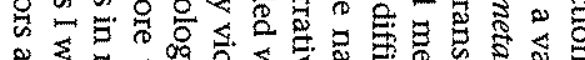

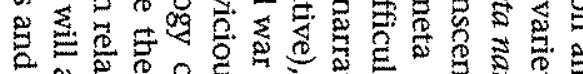

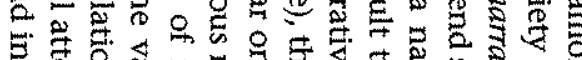

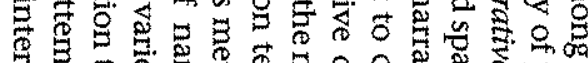

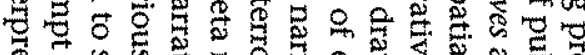

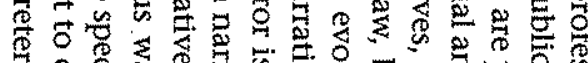

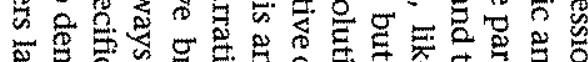

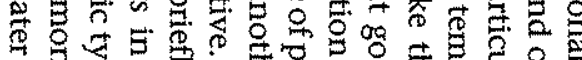

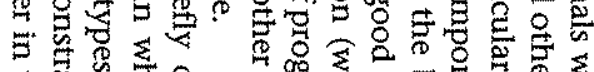

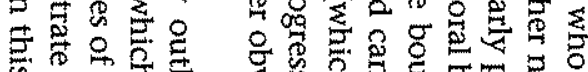
品苛

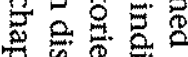

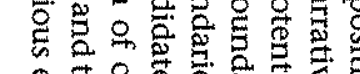

की

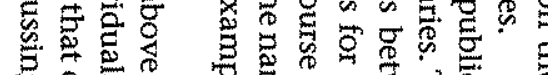

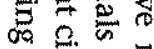

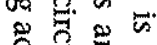

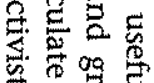

要苔

83

宽它

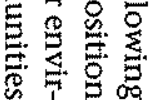

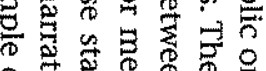

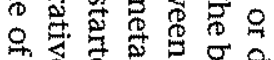

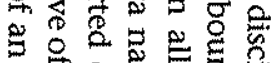

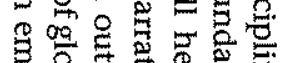

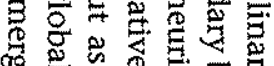

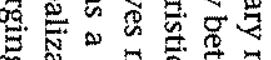

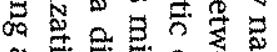

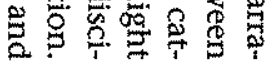




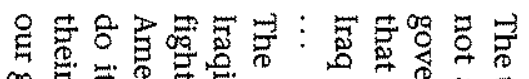
역

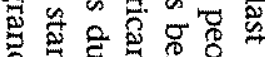

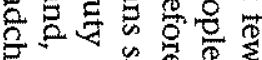

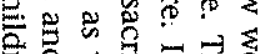

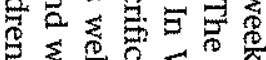
$\sum_{0}=\sum_{0}$

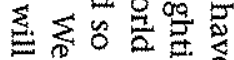
更声哥。

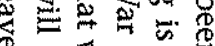
(

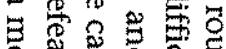

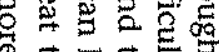

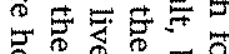
要

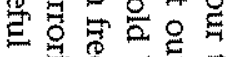

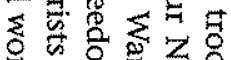

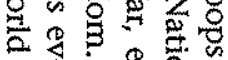
s.

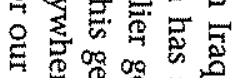
等 敦器

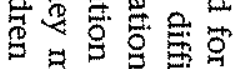

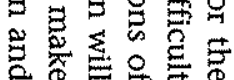

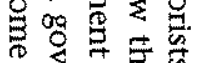
政

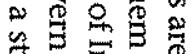
3.

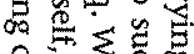
然

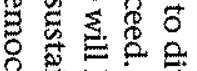
过实的 a

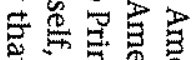

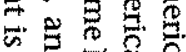
$2 z^{2}$

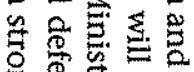
品 열

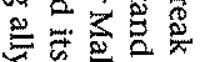

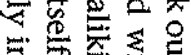
anctis

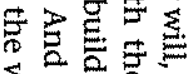

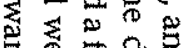
更

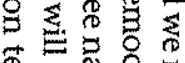

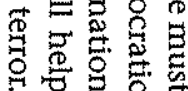

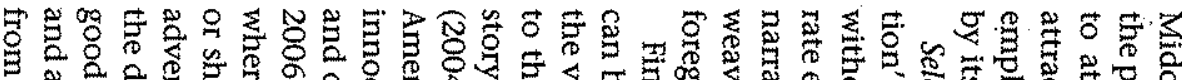

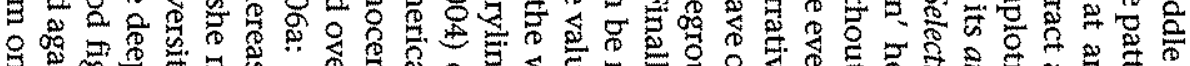

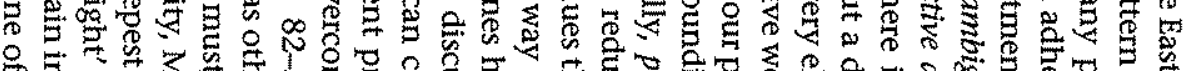

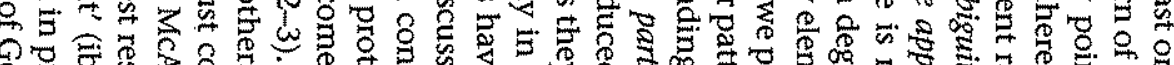

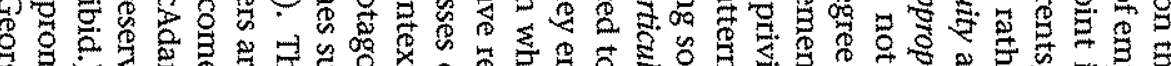

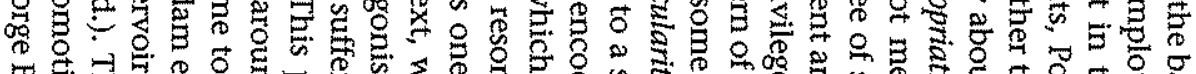

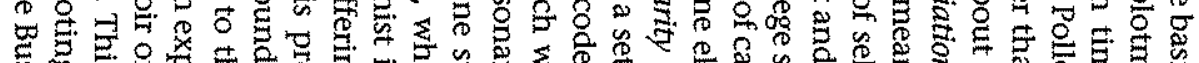

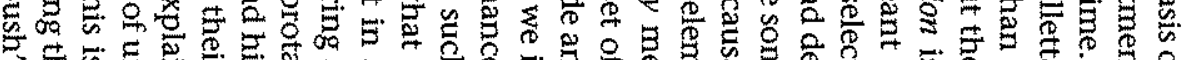

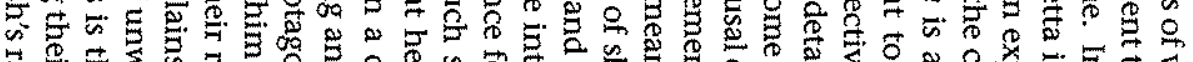

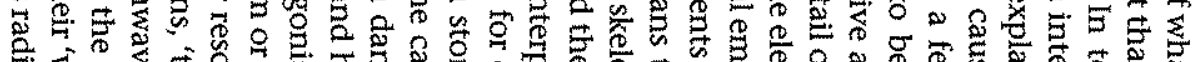

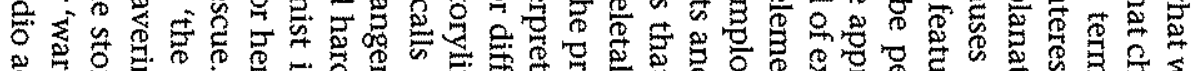

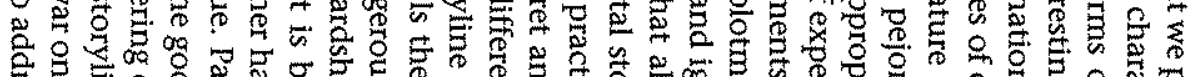

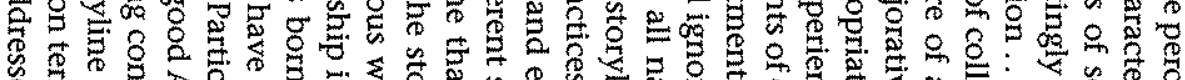

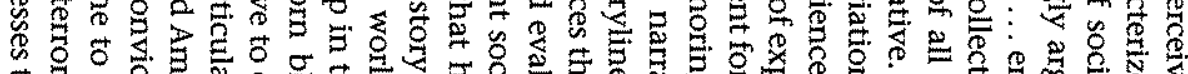

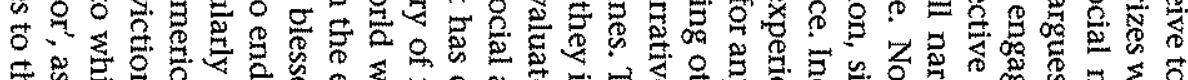

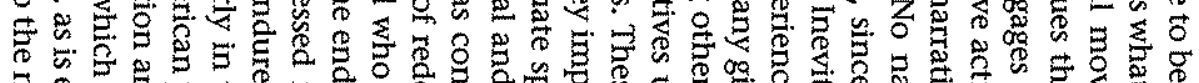

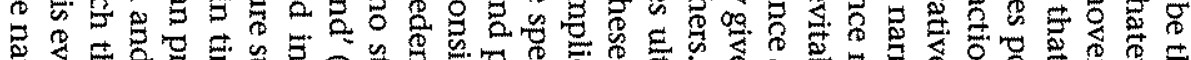

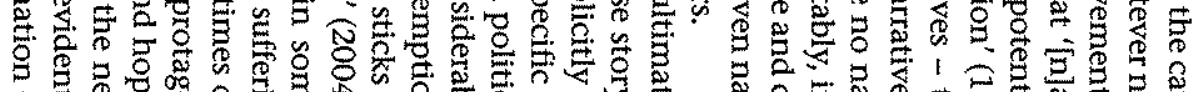

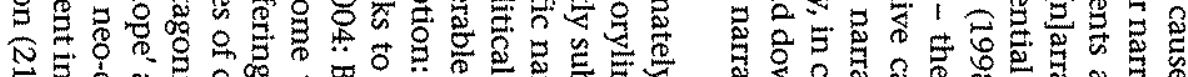

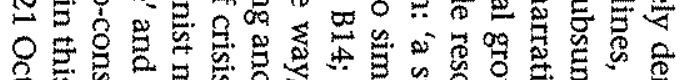

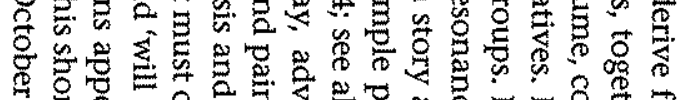

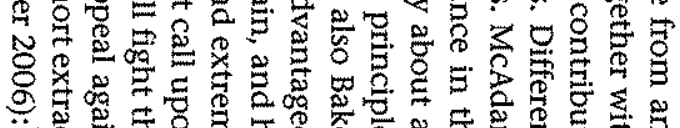

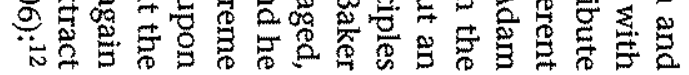

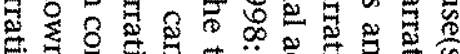

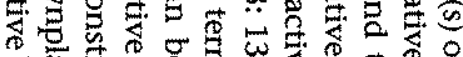

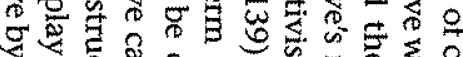

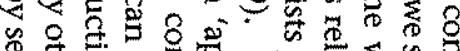

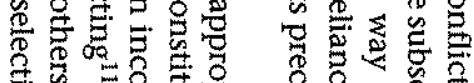

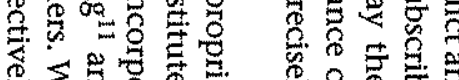

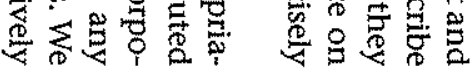

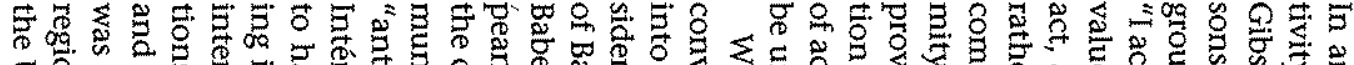

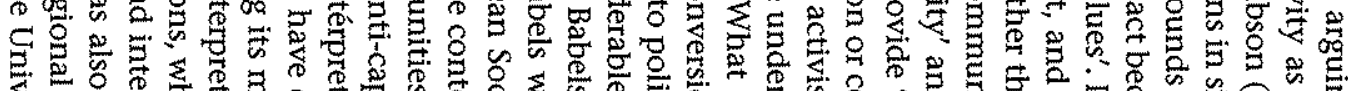

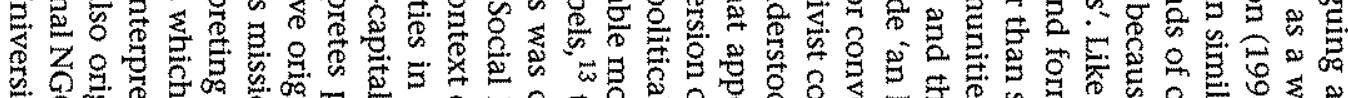

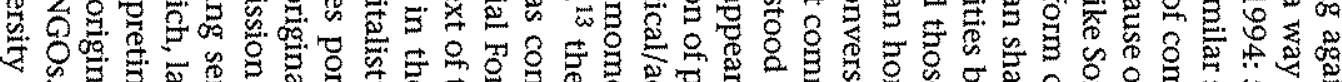

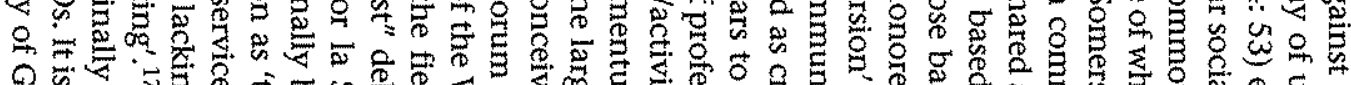

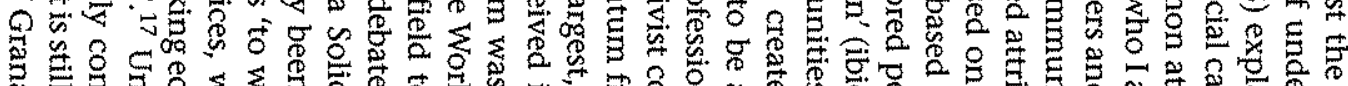

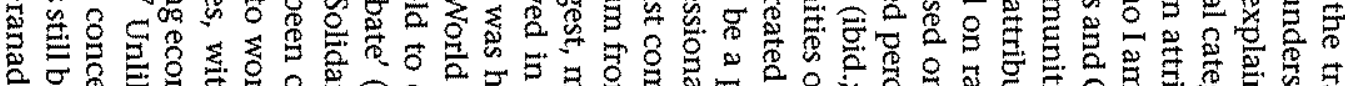

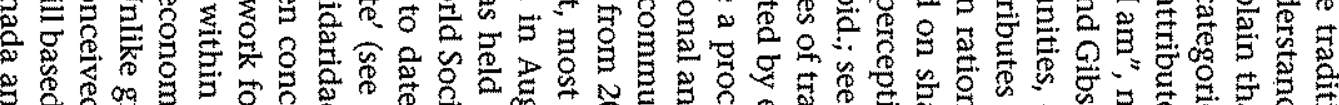

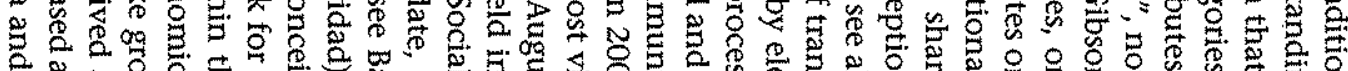

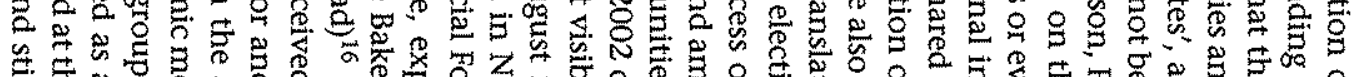

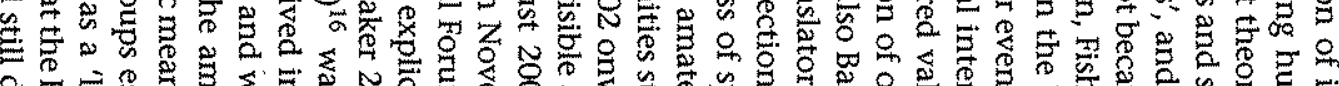

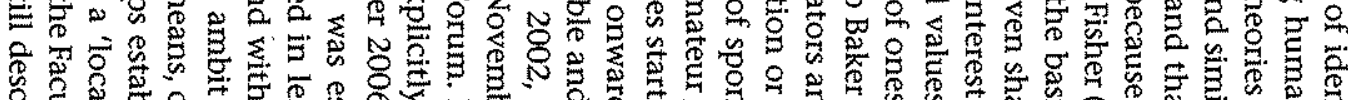

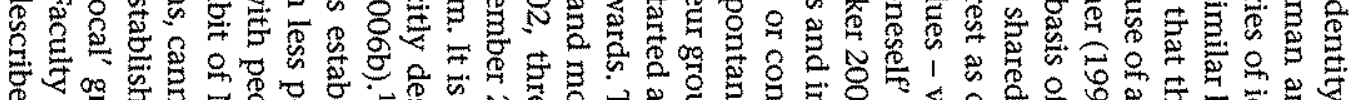

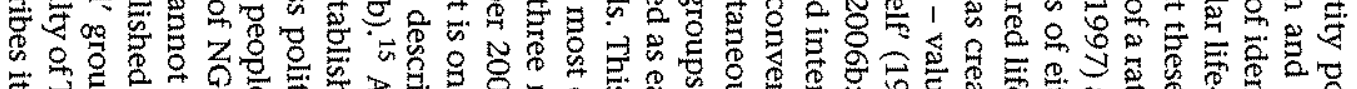

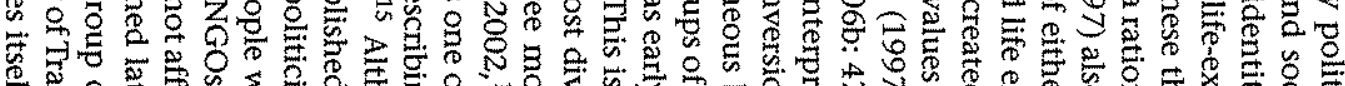

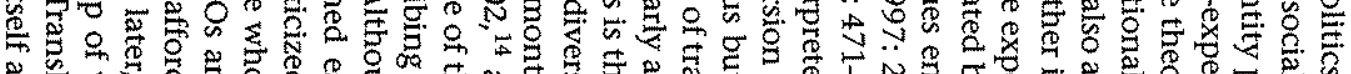

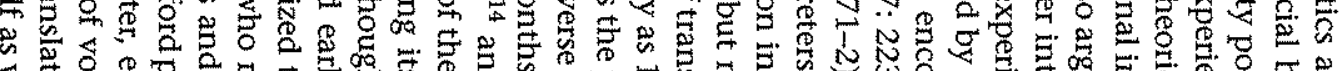

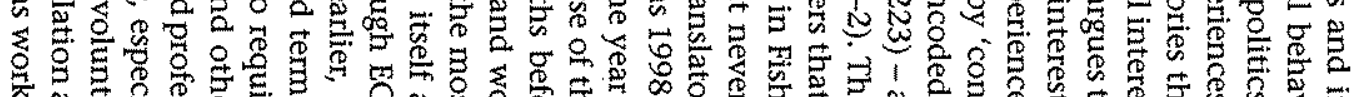

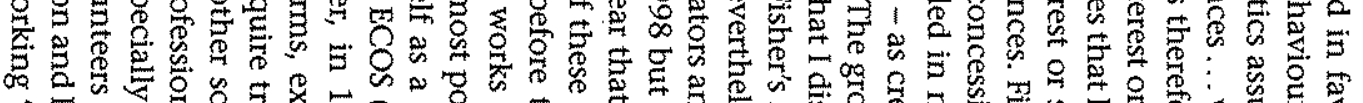

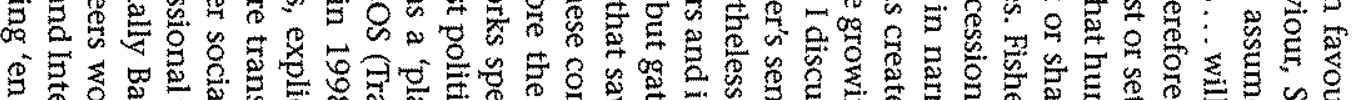

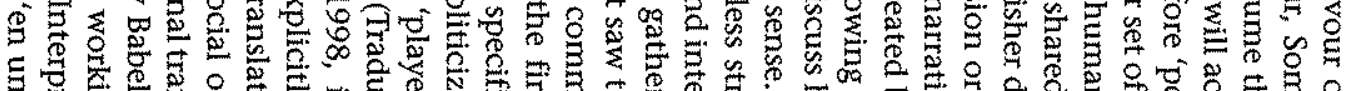

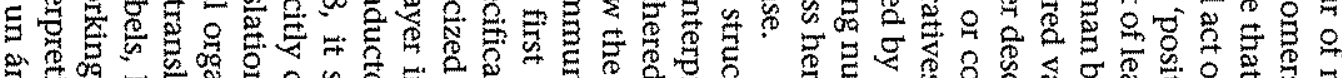

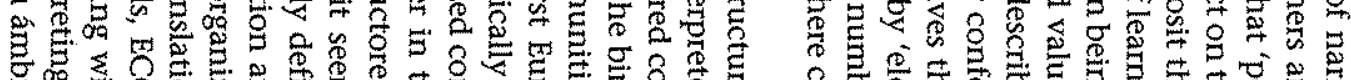

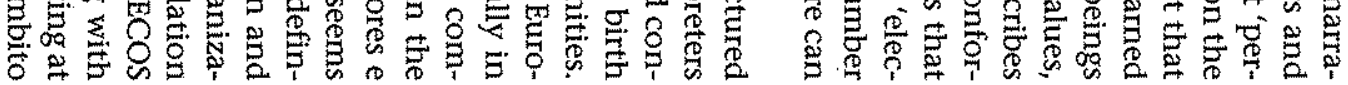

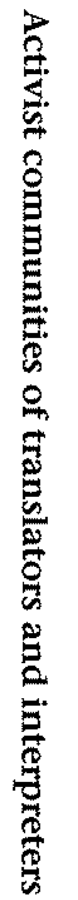

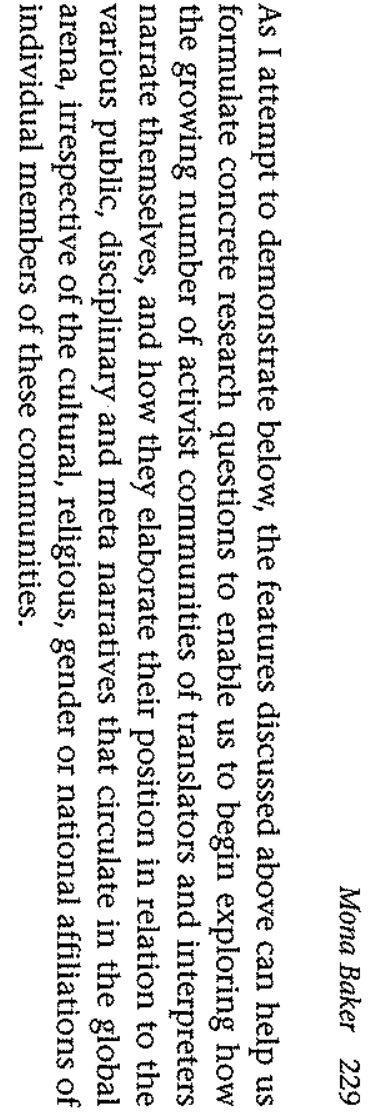




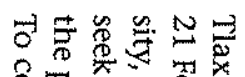

묭

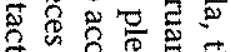

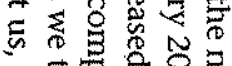

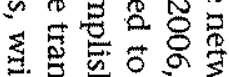

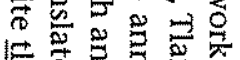

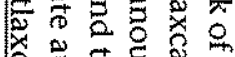

今

畄总恶总

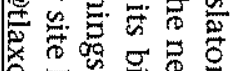

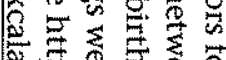

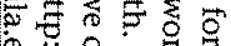

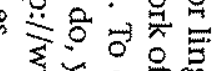

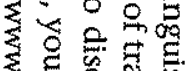

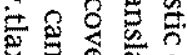

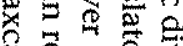

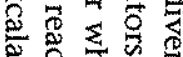

\& 0 \%

$\sum_{0}$

3 录

$\stackrel{2}{\circ} \stackrel{0}{\circ}$

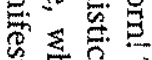

造 20

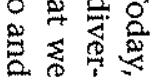

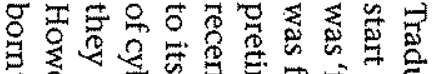

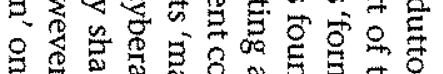

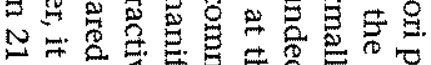

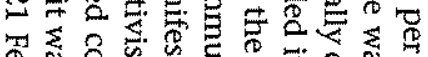

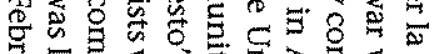

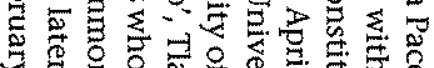

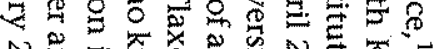

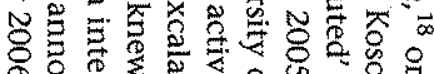

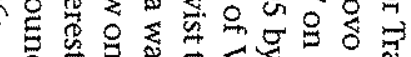

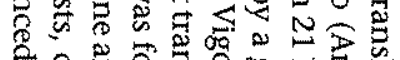

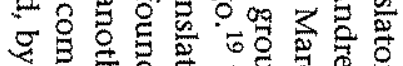

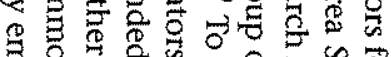

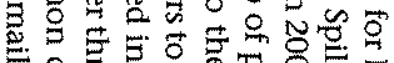

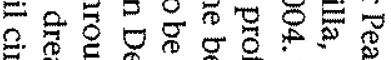

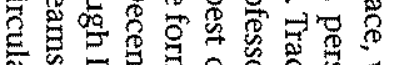

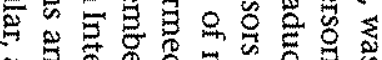

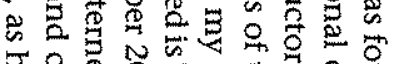

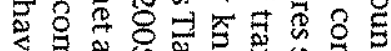

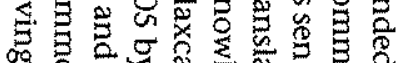

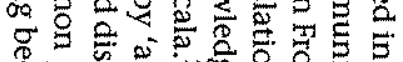
马ु

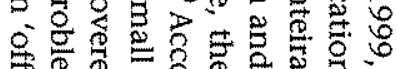
웅

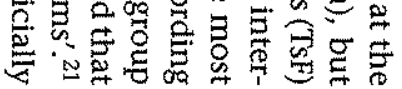

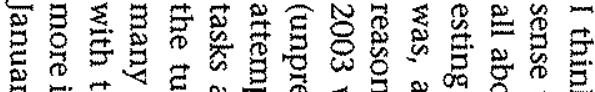

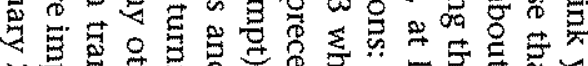

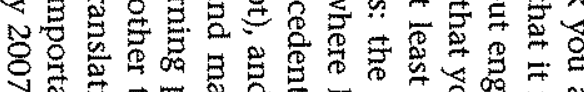

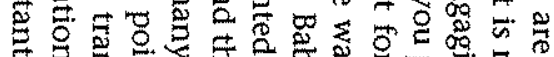

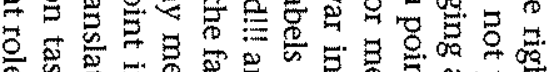

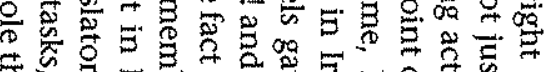

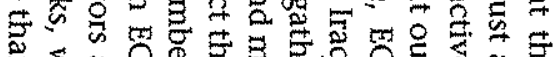

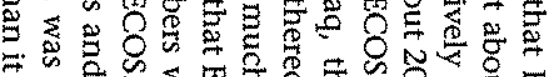

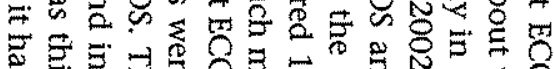

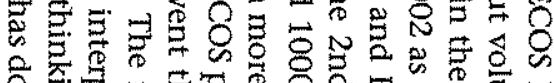

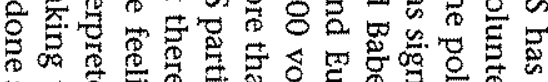

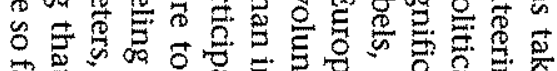

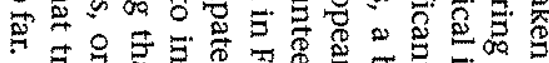

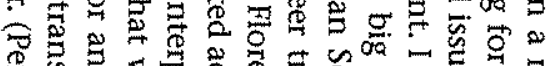

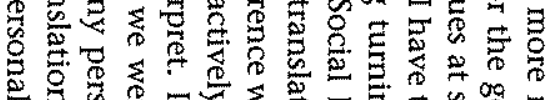

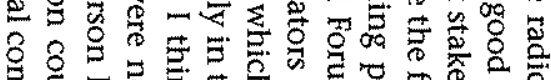

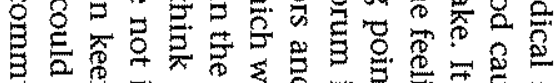

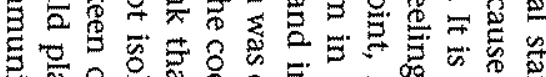

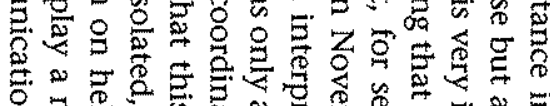

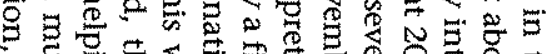

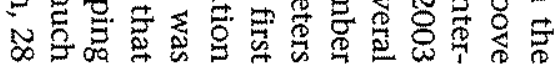

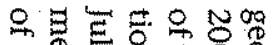

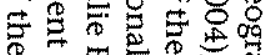

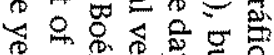

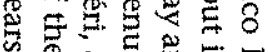

N

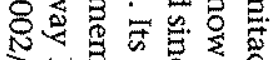

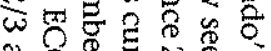

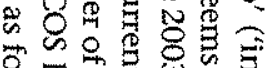

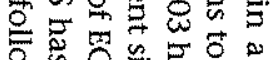

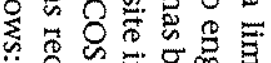

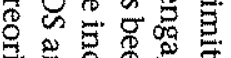

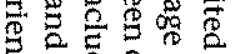

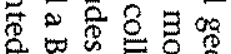

뉼

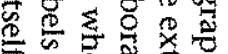

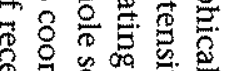

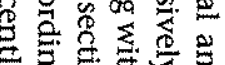

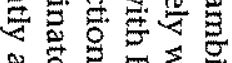

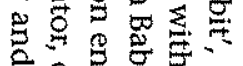

요욜

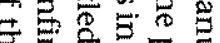

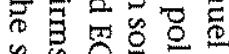

骂里象

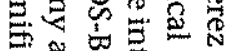

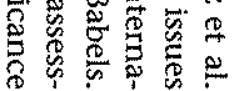

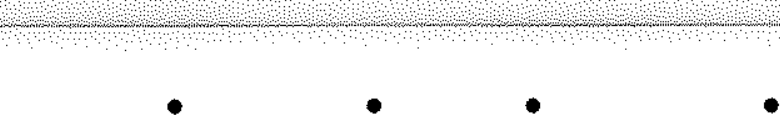

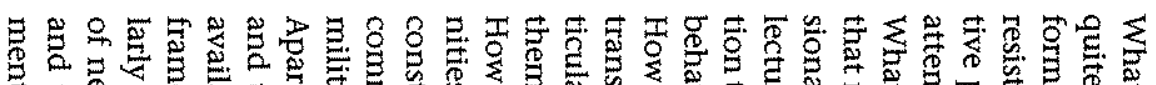

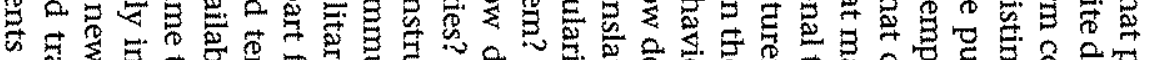

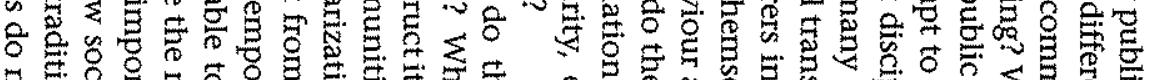

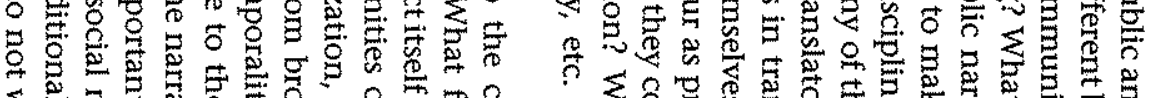

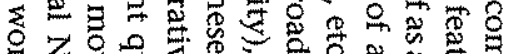

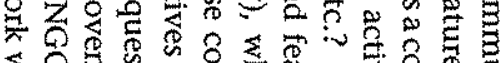

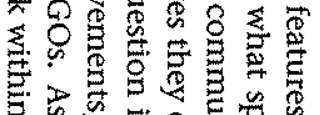

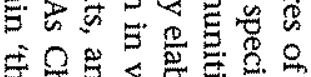

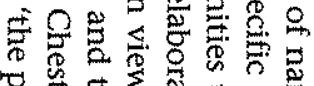

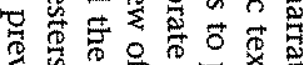

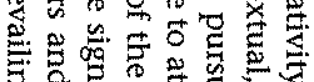

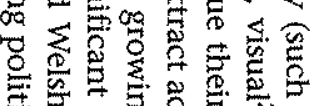

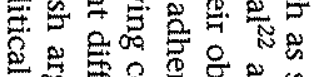

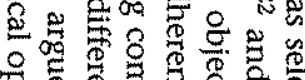

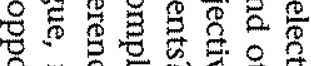

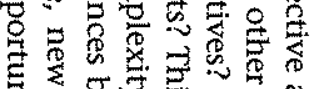

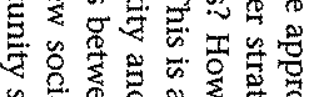

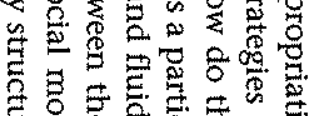

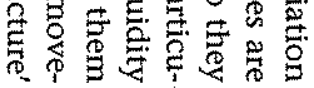

过䨪

旅蛋

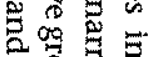

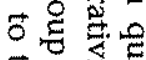

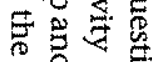

웅응

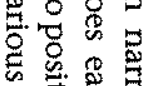

क

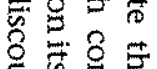

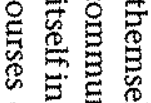

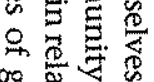

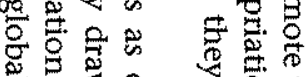

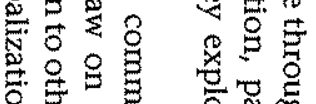

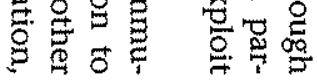

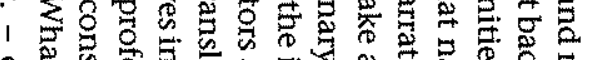

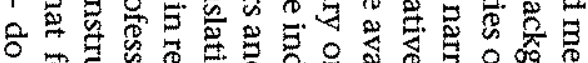

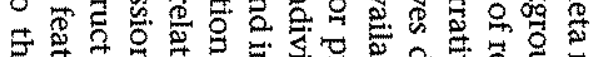

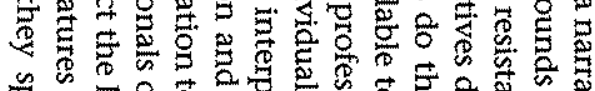

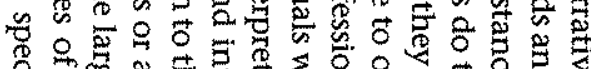

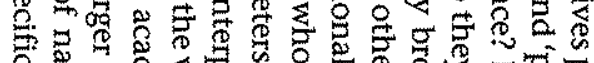

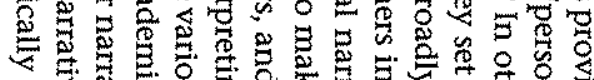

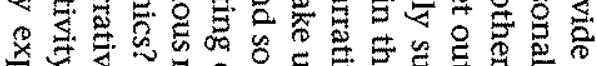

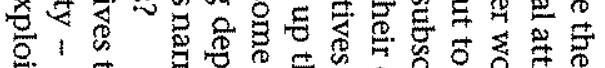

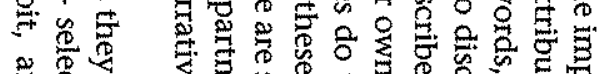

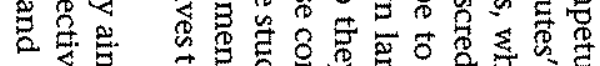

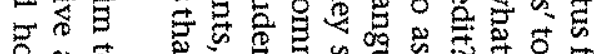

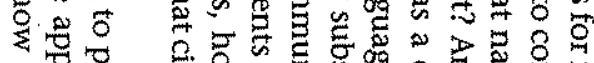

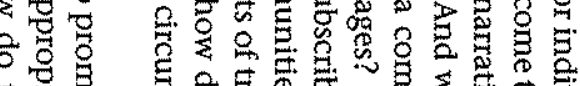

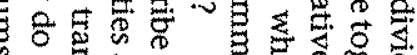

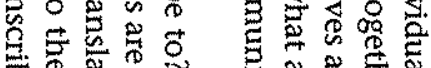

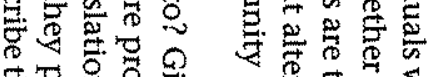

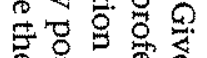

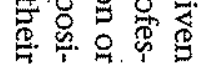

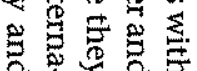

을 윱

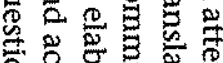

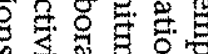

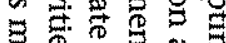

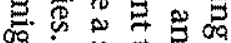

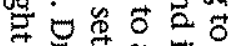
马ึ 总总总蛋

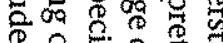
율

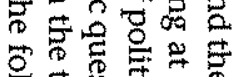

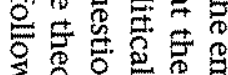

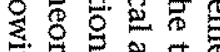

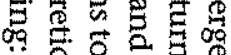

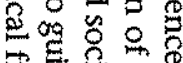

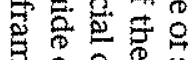

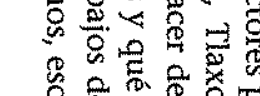

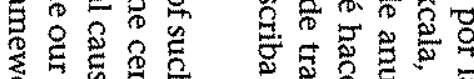

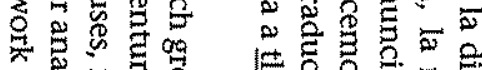
至 농 일 总莺㤩

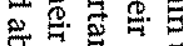
究㝵是宫 율유. 密惫总要。

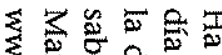
起象吕

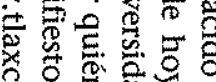
跣

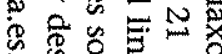

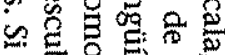

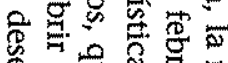

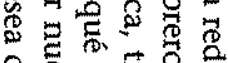

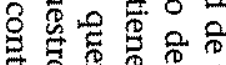
的里包 농용 \%

స्र्टि

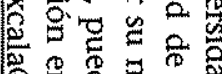

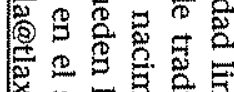

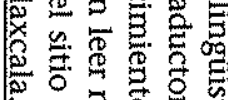

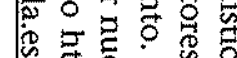

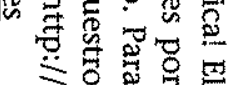




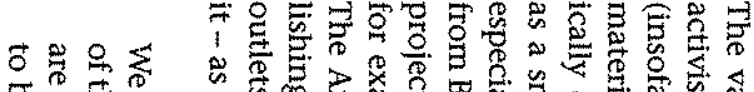

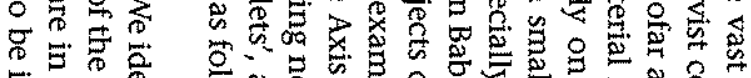

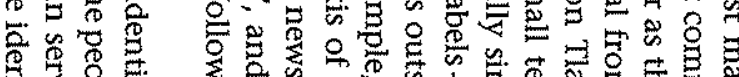

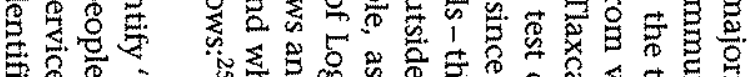

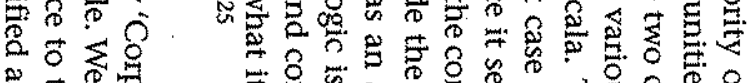

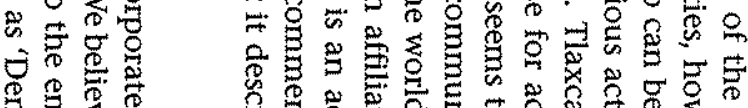
응

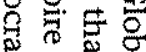

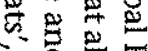

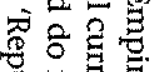
후용 要 类贾要 ᄋ马

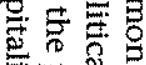
荧苋总象 ० $\sum \stackrel{0}{0}$

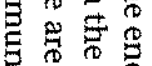

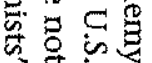

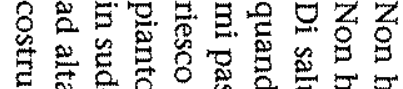

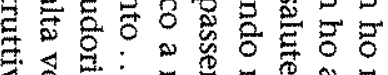

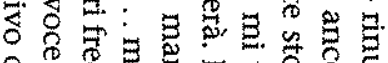

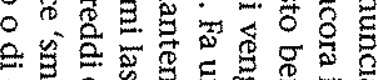
응

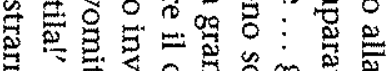

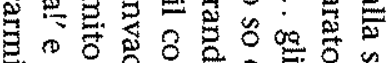

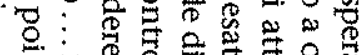

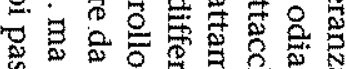

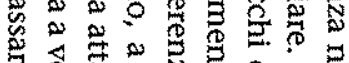

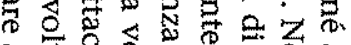

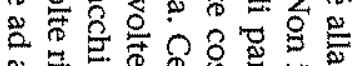

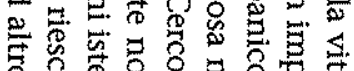

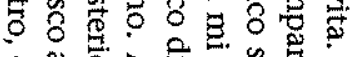

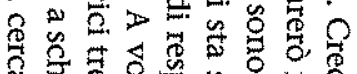

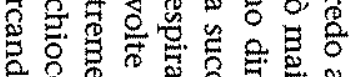

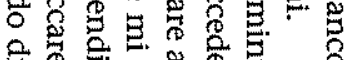
蛋

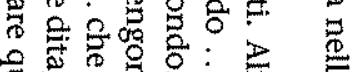

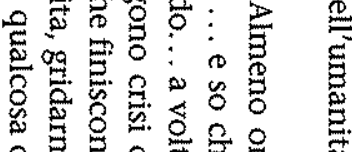

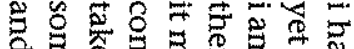

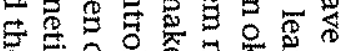

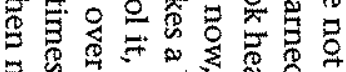

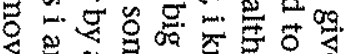

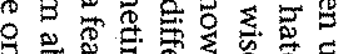

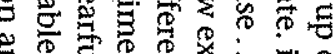

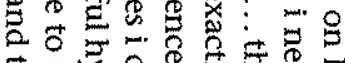

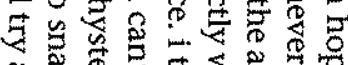

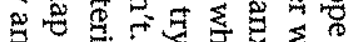

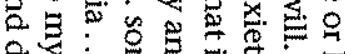

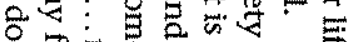

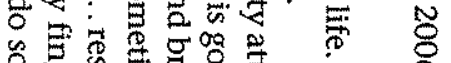

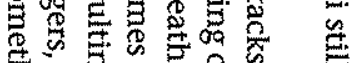

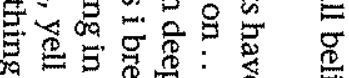

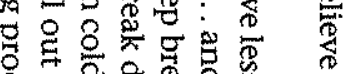

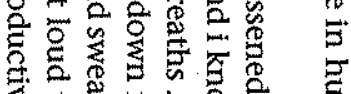

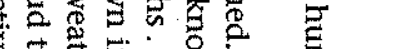

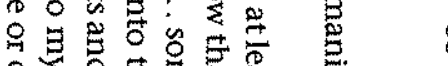

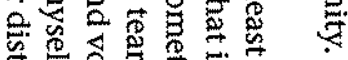

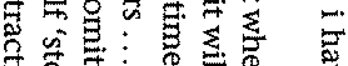

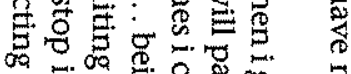
.

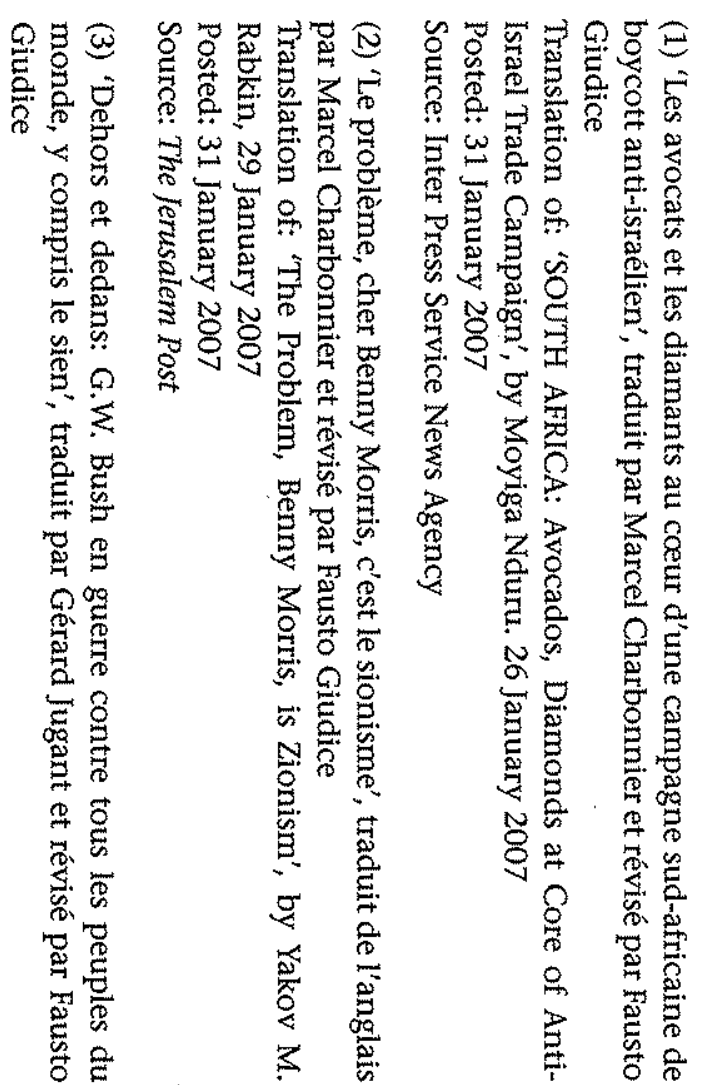

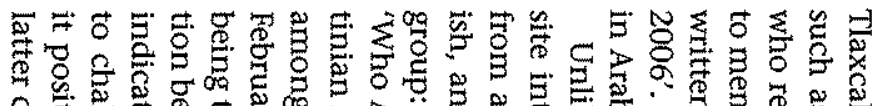

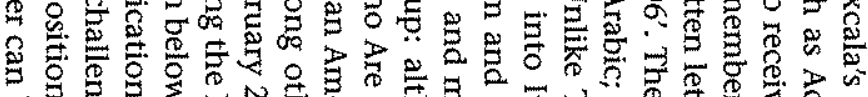

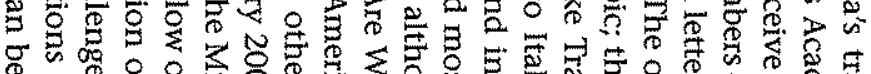

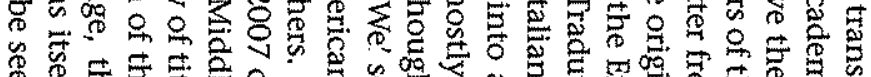

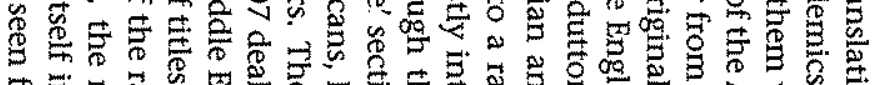

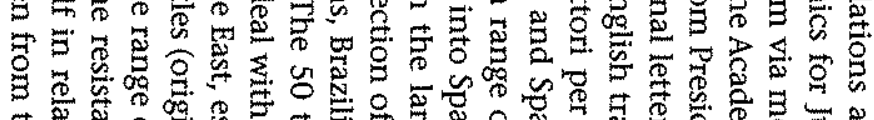

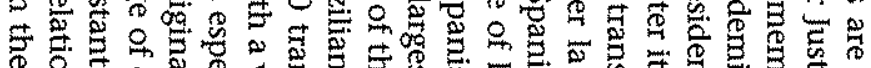

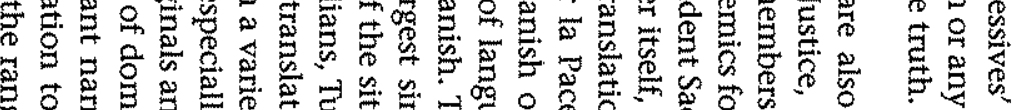

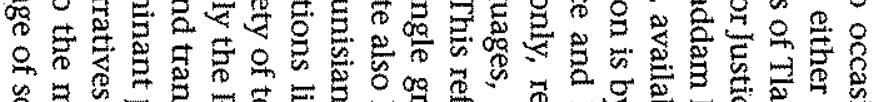

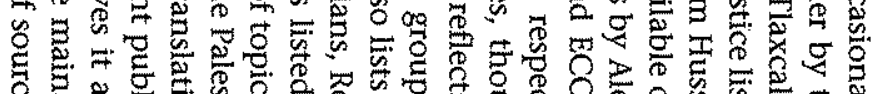

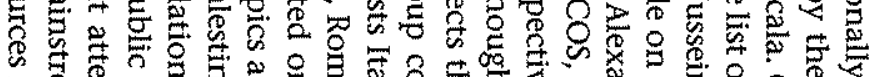

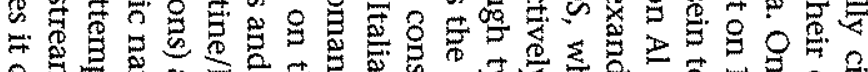

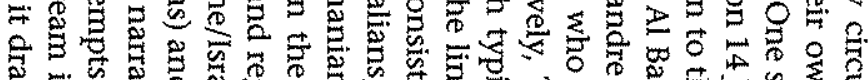

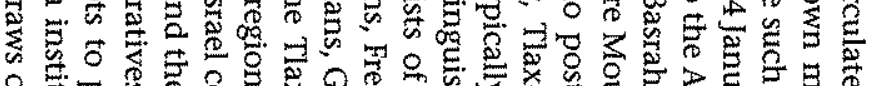

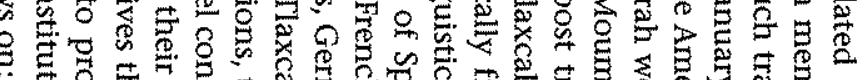

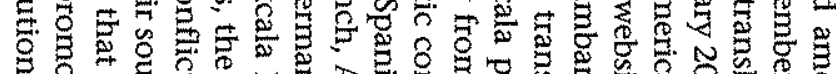

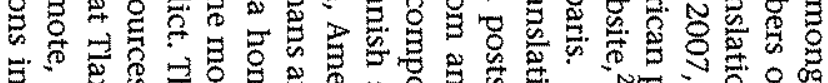

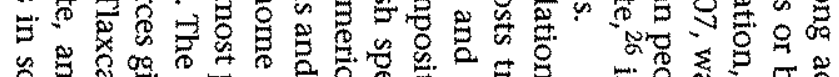

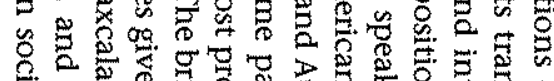

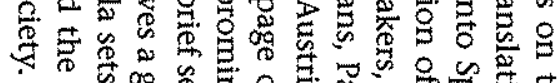

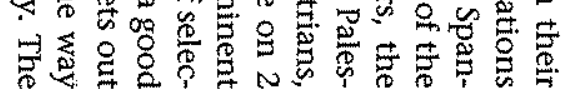

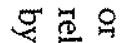

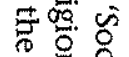
象 . 初

욜. 훙요 웅 点 政 这 융 富 要 芑

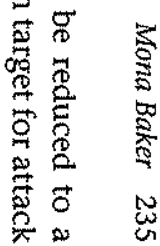




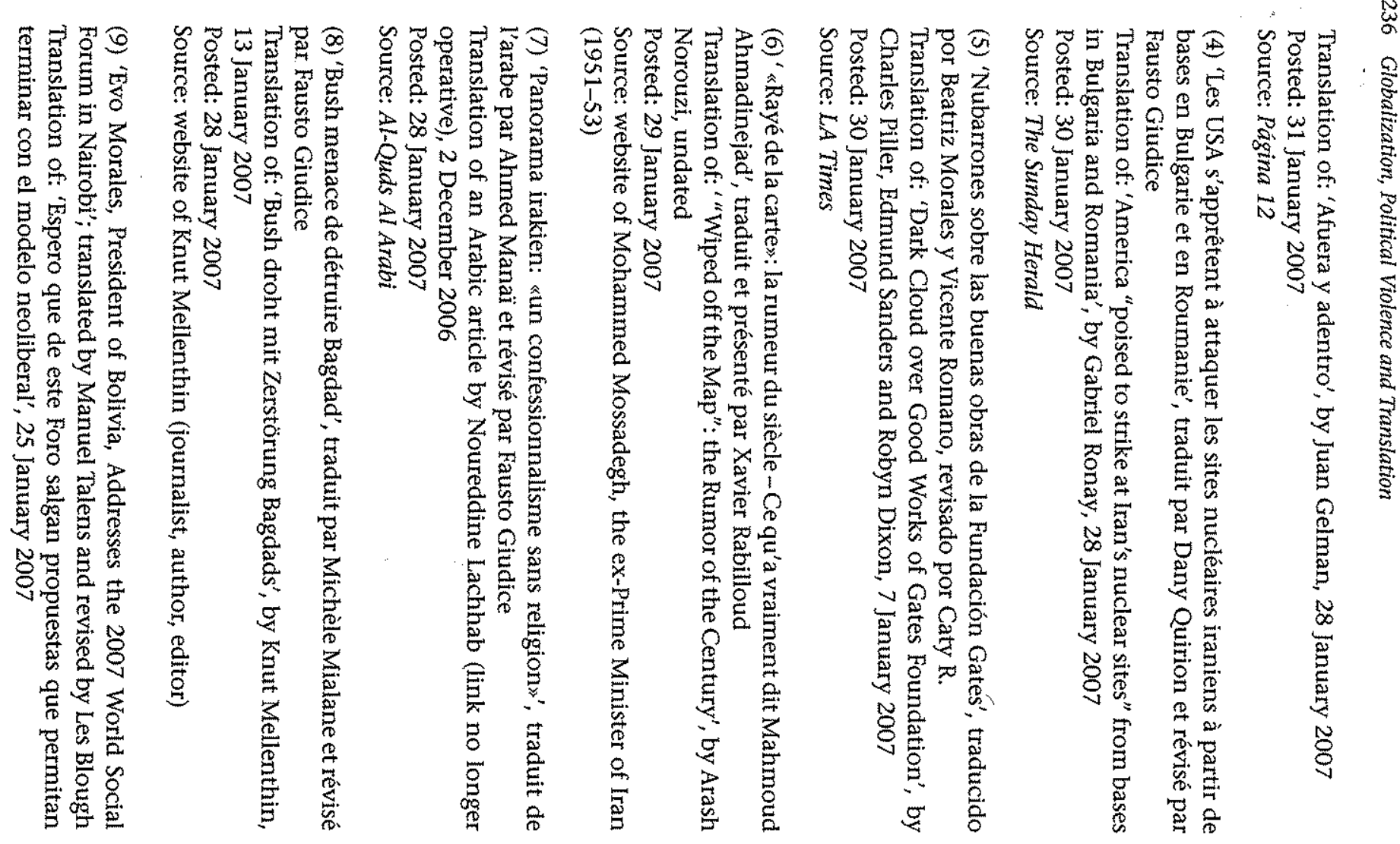

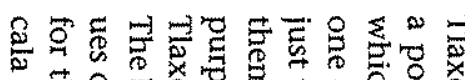

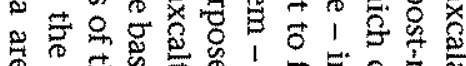

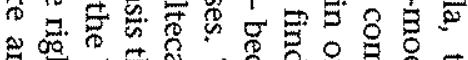

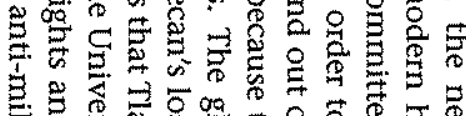

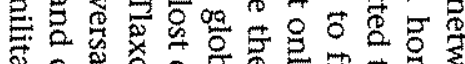

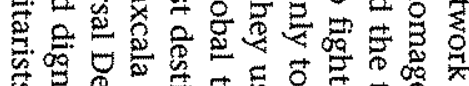

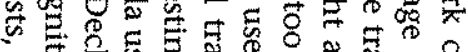

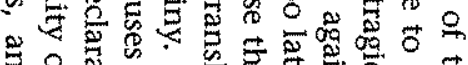

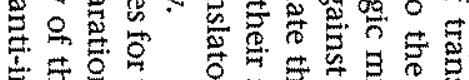

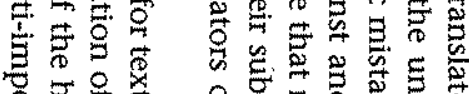

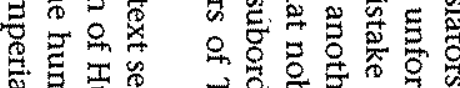

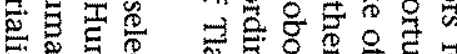

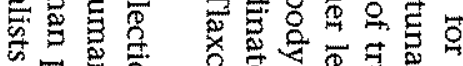

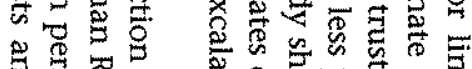

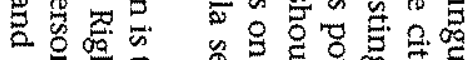

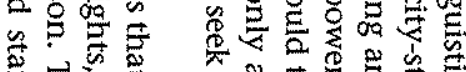

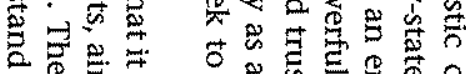

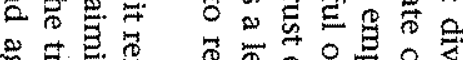

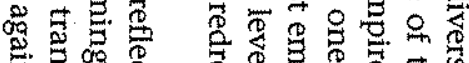

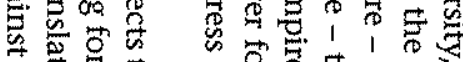

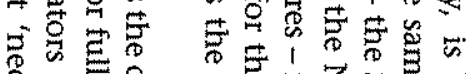

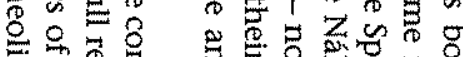

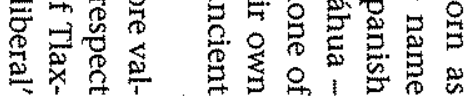

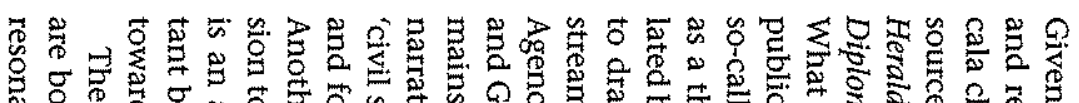

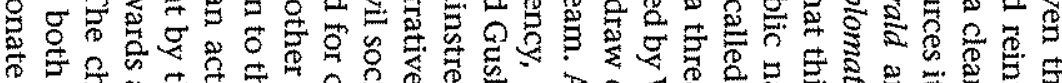

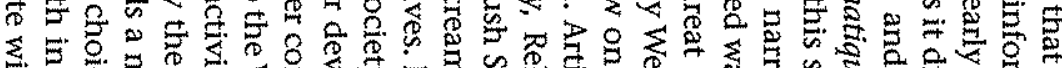

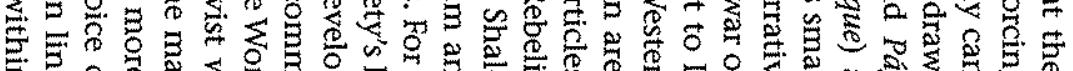

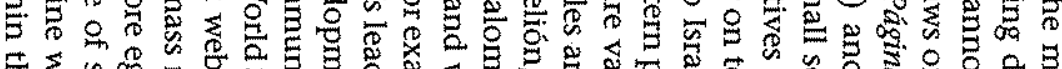

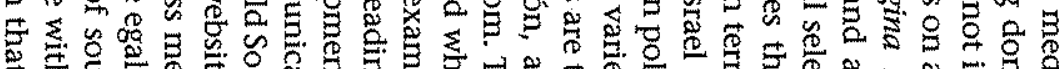

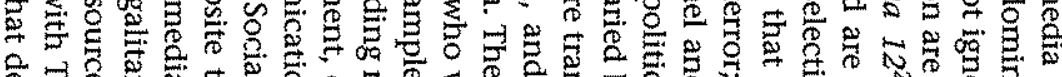

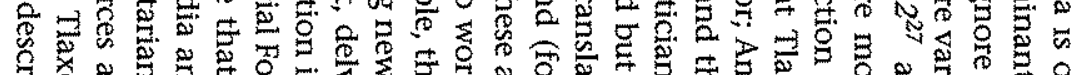

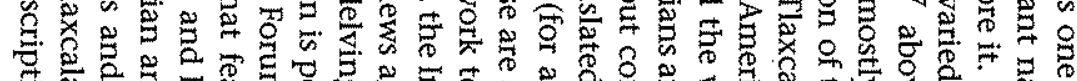

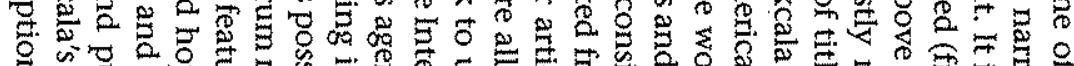

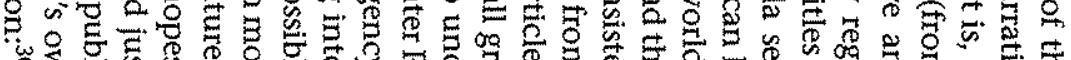

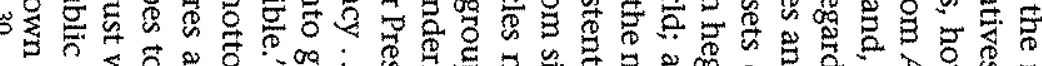

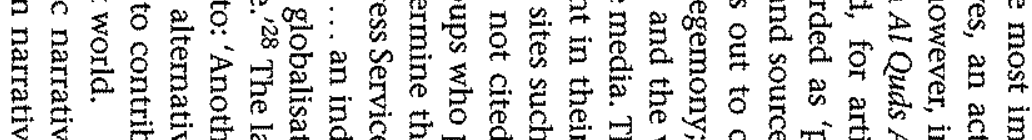

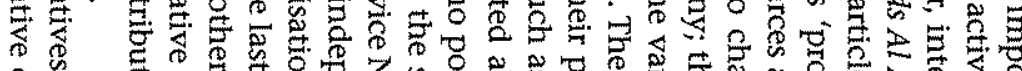
융

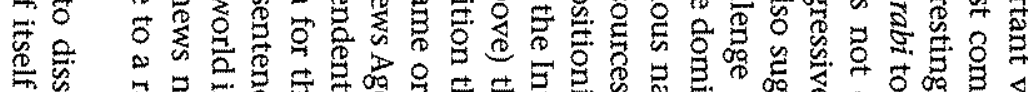

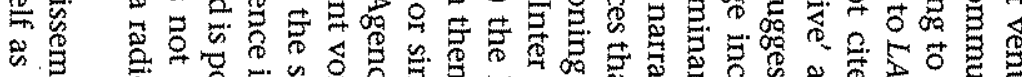
局

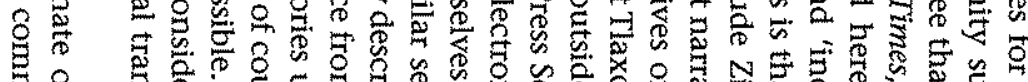

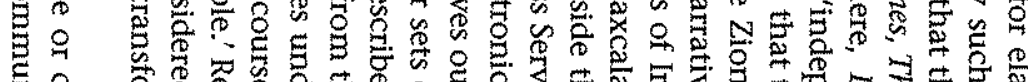

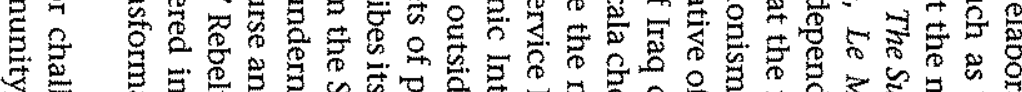

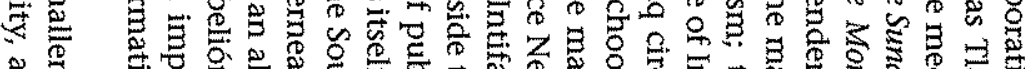

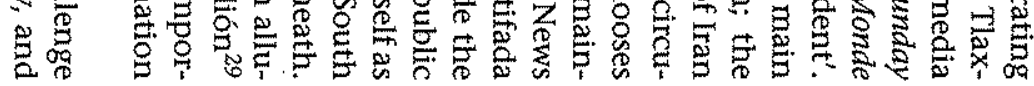

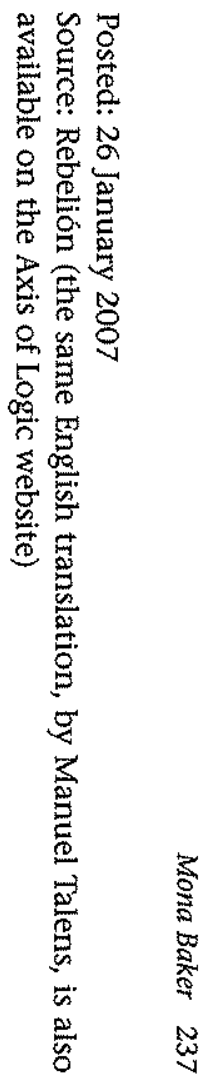




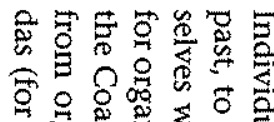

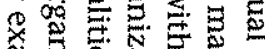

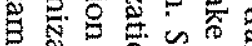

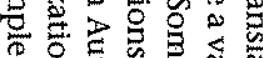

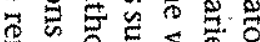

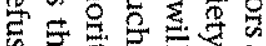
吉艺的员

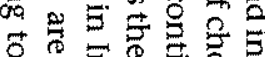

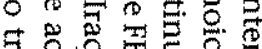

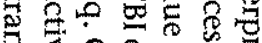

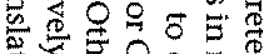

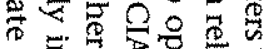

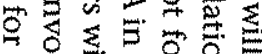

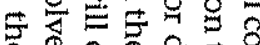

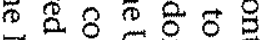

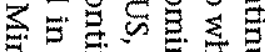

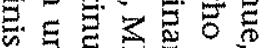

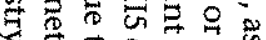
$\circ$ 유료

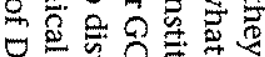

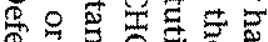

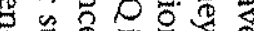
बิ

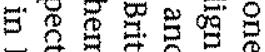

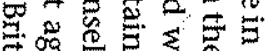

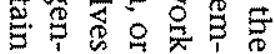

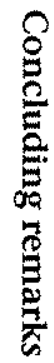

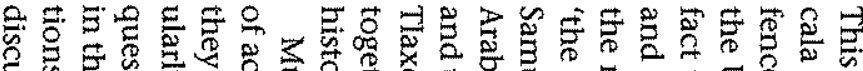

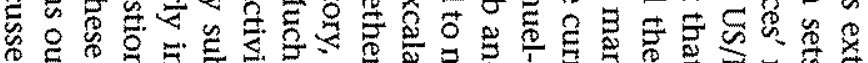

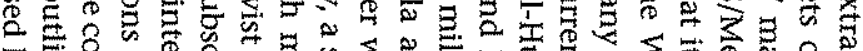

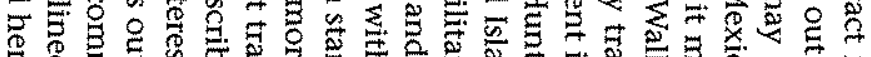
\%

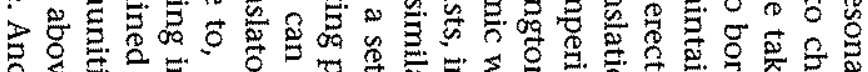

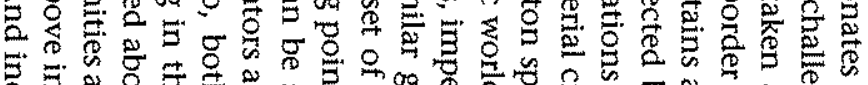

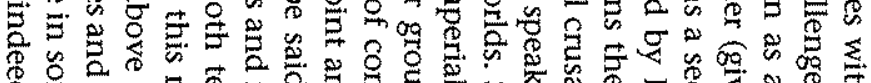

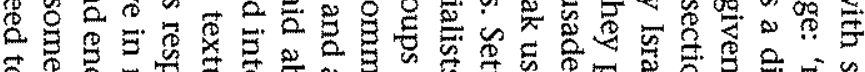
不

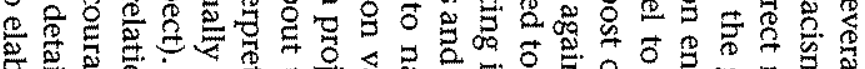

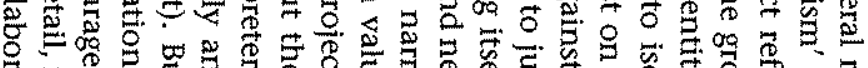

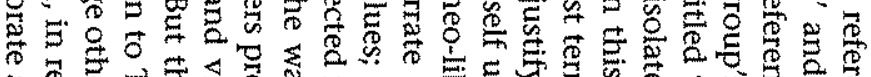

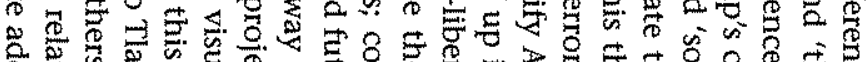

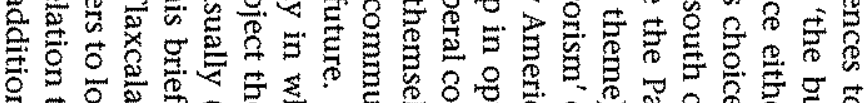

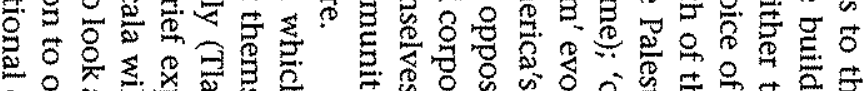
일

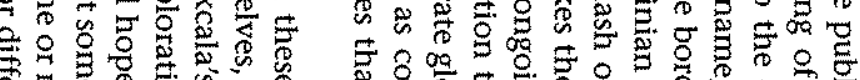

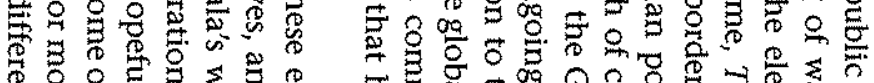

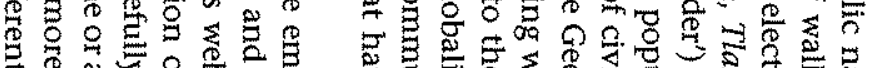

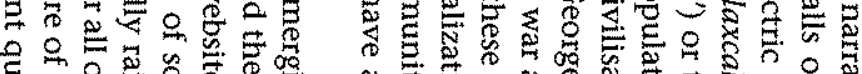

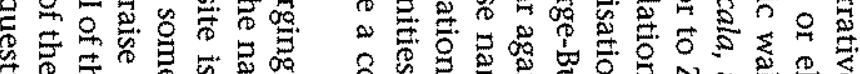
.

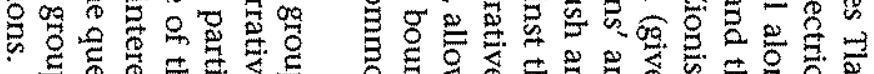

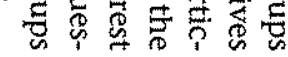

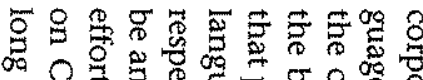

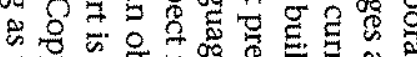

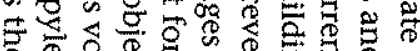

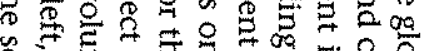

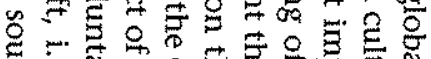

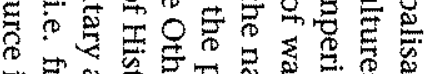

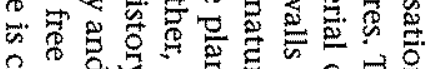

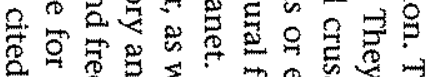

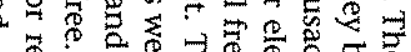

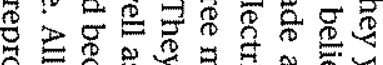

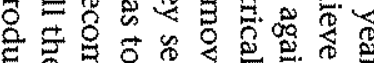

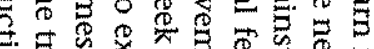

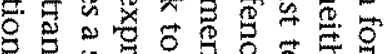

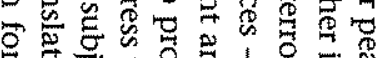

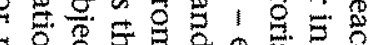

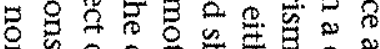

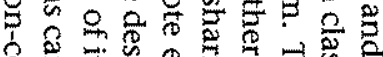

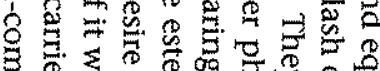

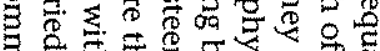

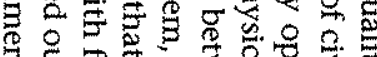

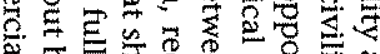

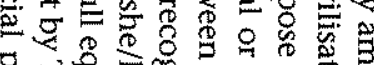

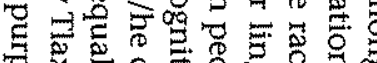

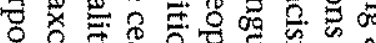

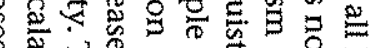

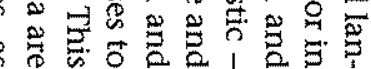

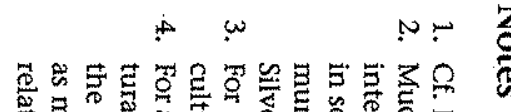

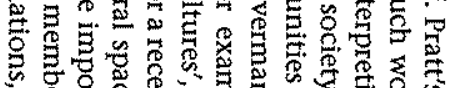

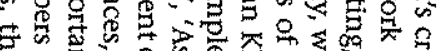

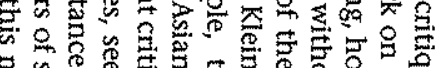

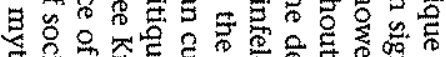

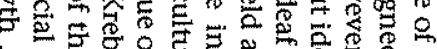
영

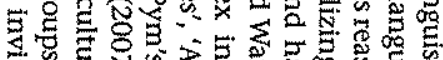

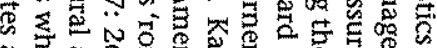

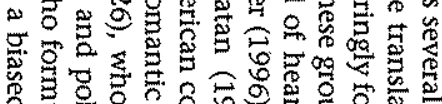

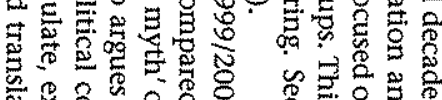

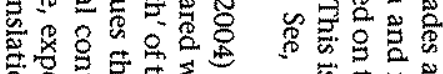

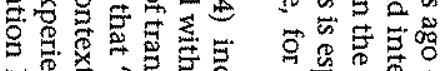

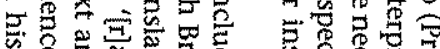

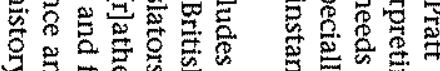

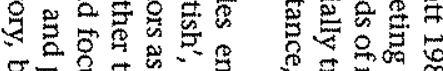

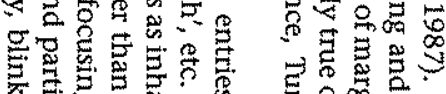

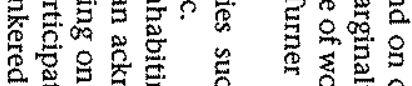

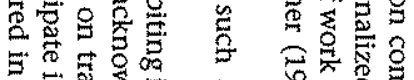

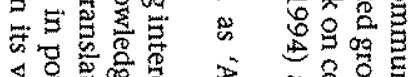

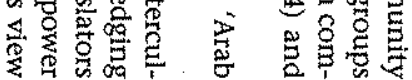

$\frac{8}{8}$

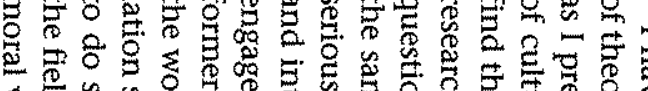

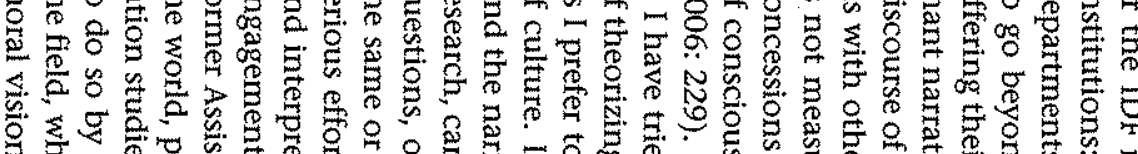

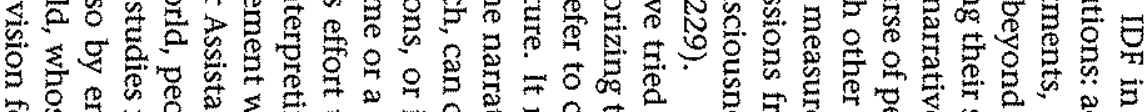

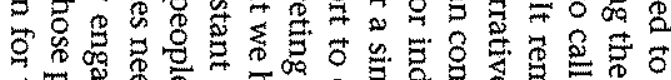

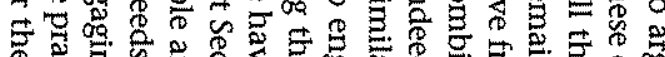

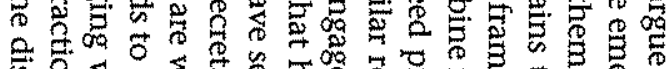

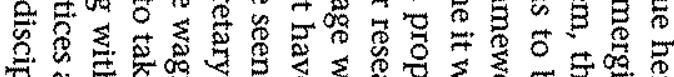

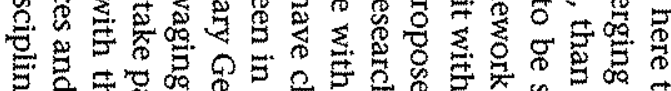

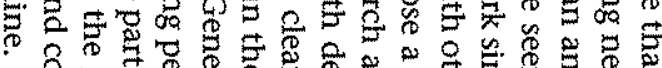

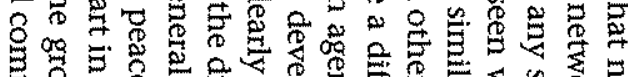

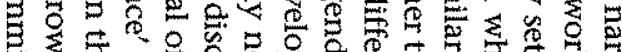

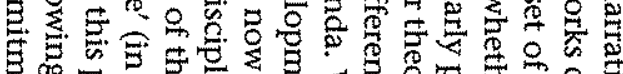

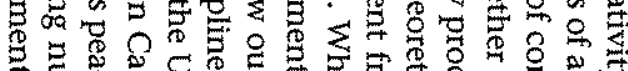

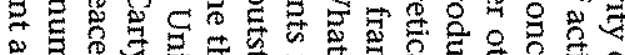

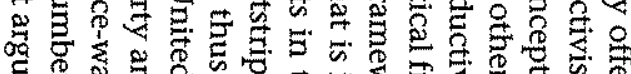

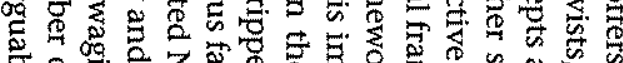

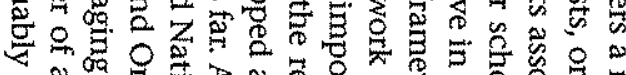

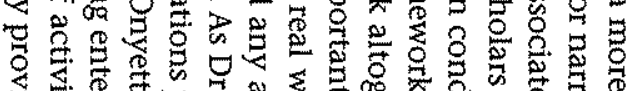

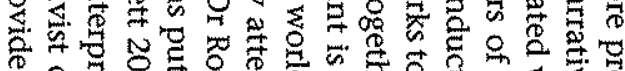

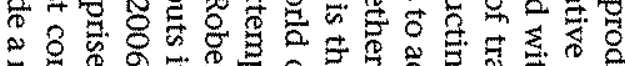

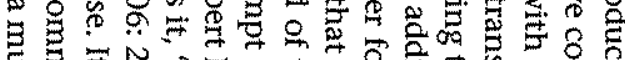

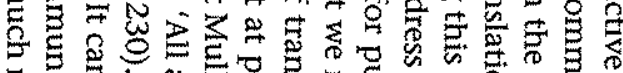

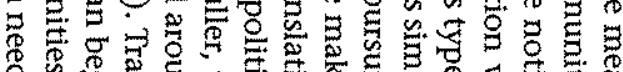

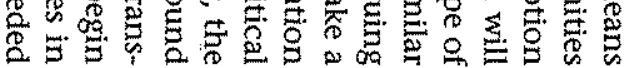

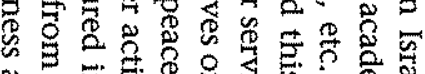

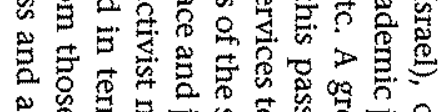
ผ

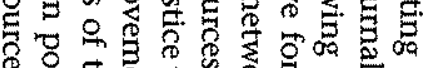

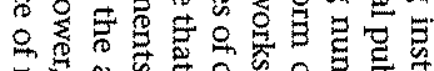

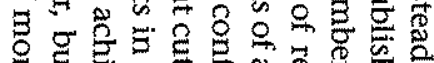

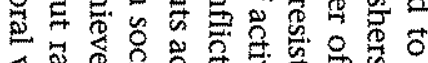

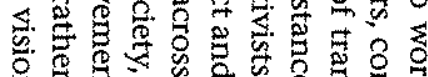
52

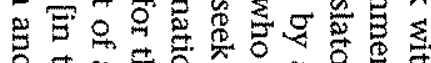

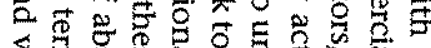

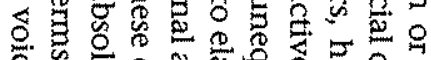

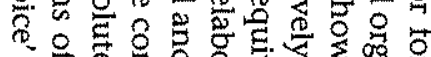

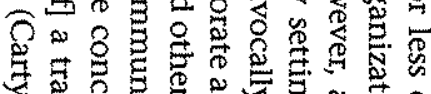

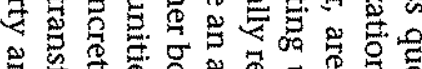

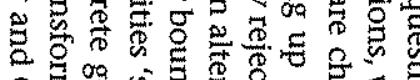

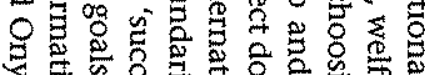

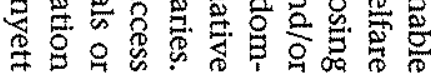




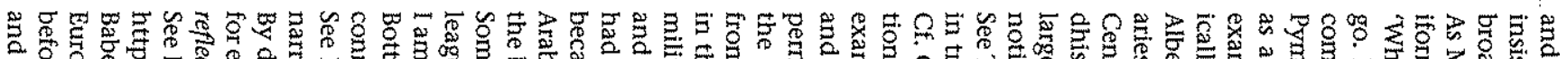

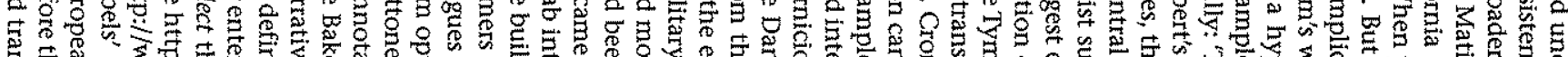

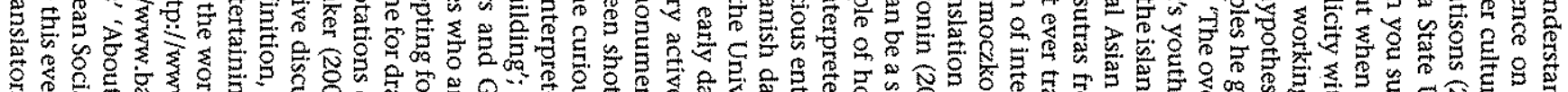

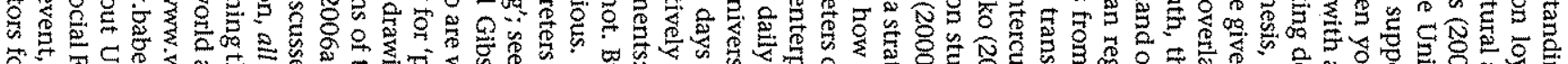

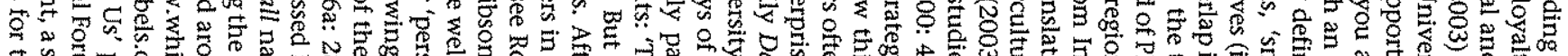

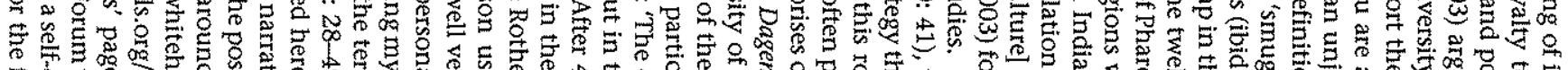

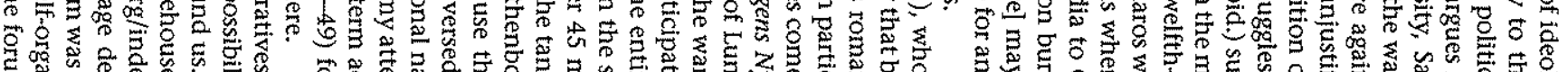

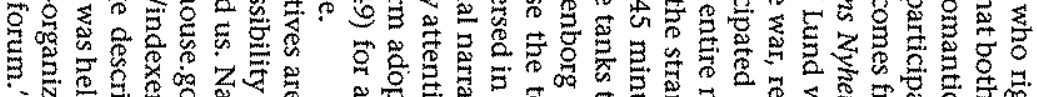

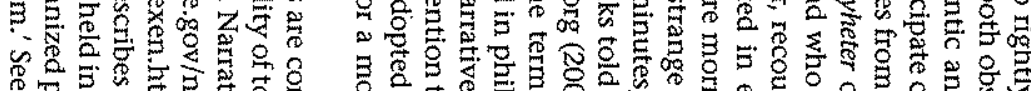

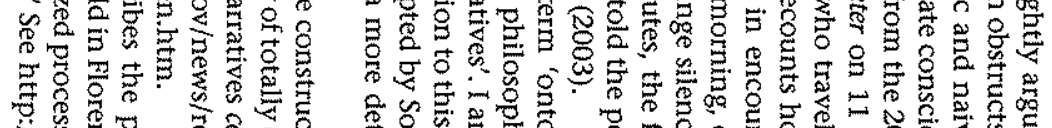

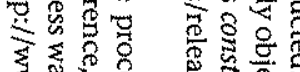

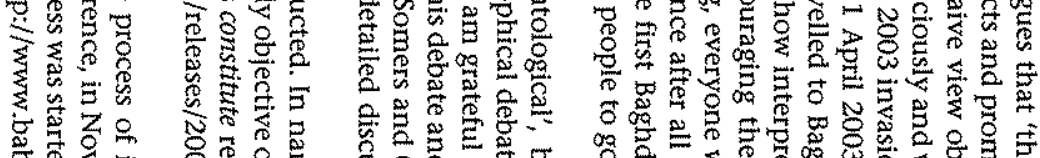

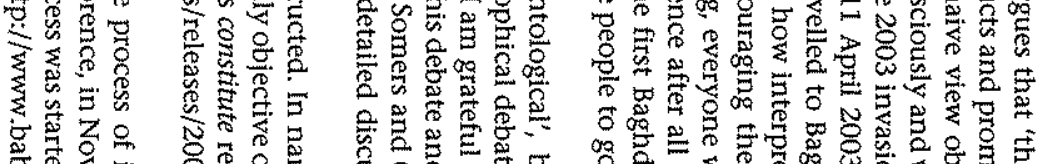

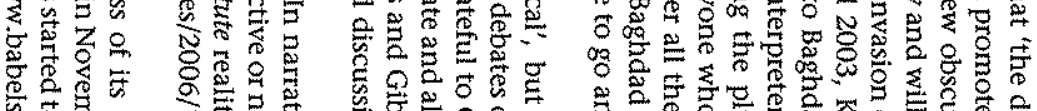

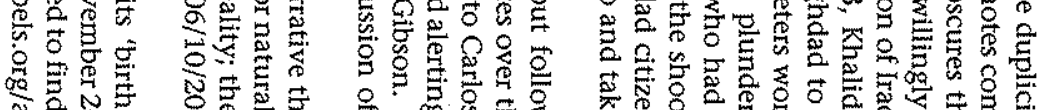

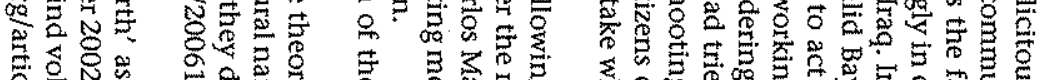

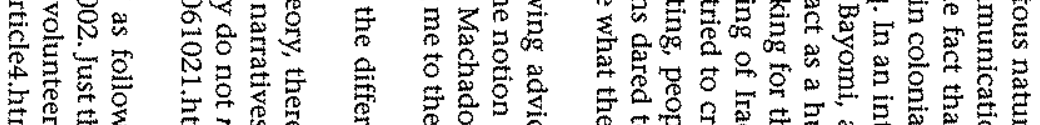

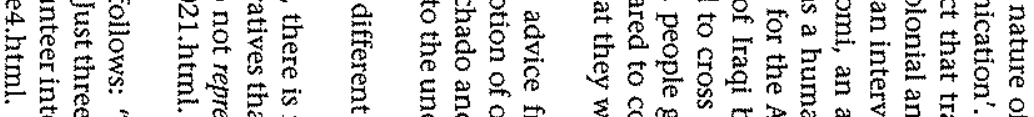

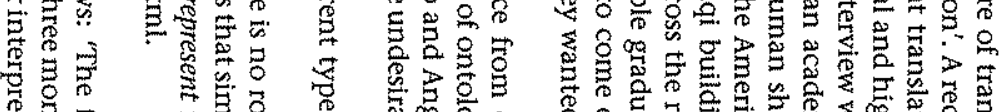

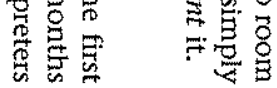

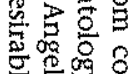

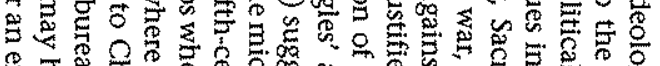

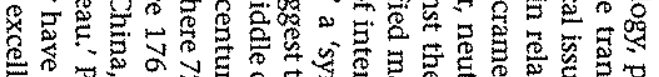

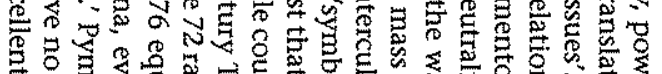

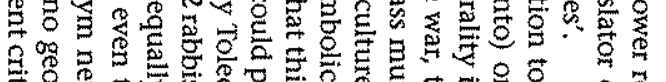

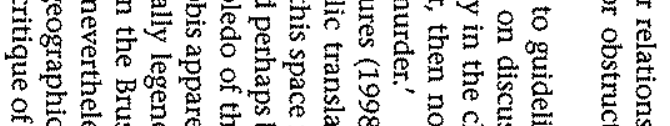

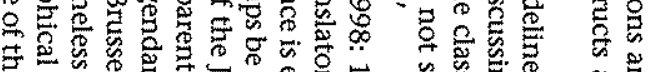

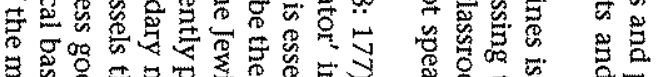

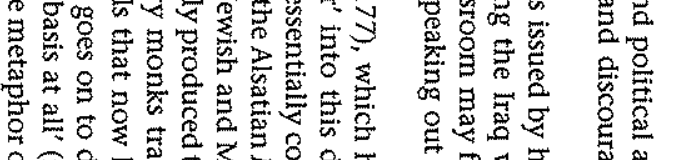

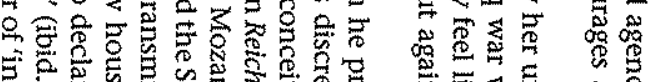

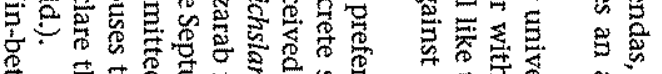

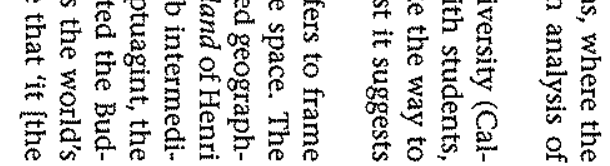

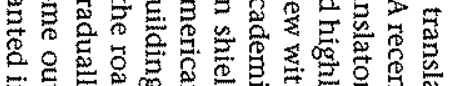
虽宫

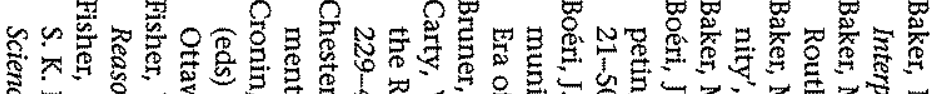

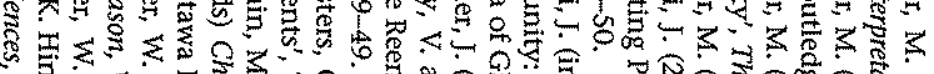

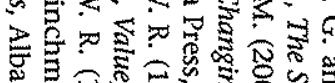

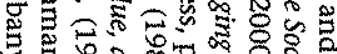

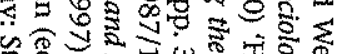

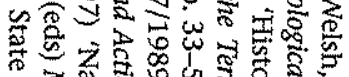

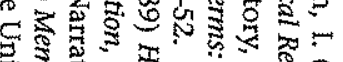

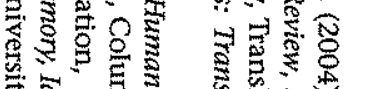

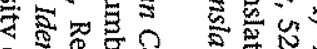

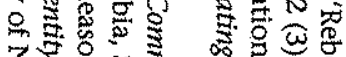

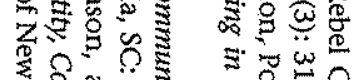

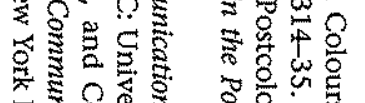

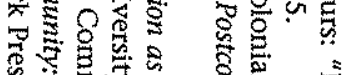
和寻定 武氠 ( is:

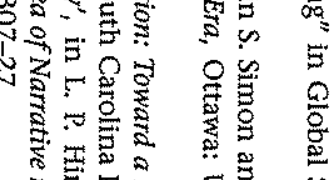

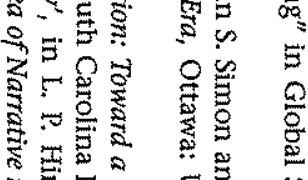

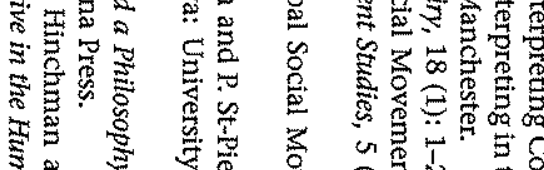

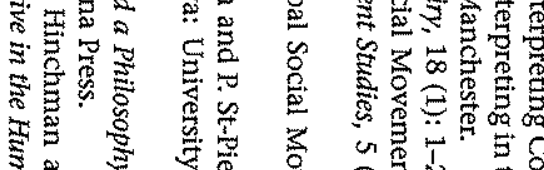

놈

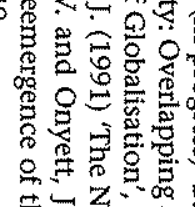

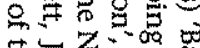

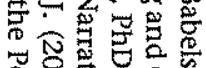

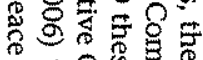

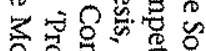

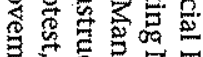

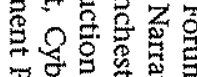

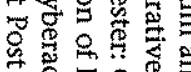

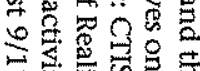

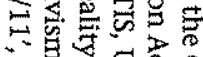

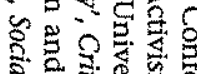

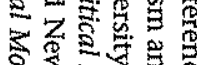

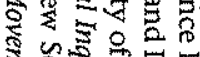

을

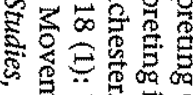

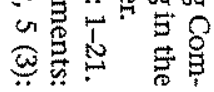

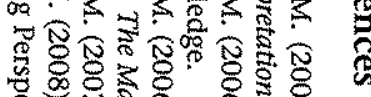

象象资

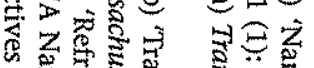

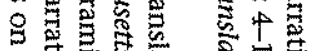

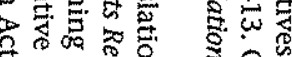

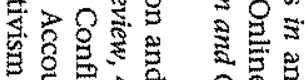

严苛出

ᄋ요을

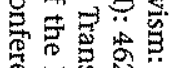

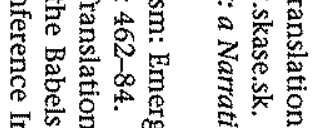

莺在的

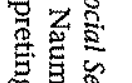

a9

उ

궁

范 苛

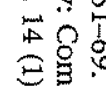

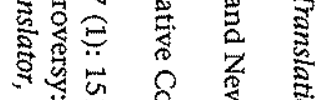

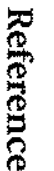

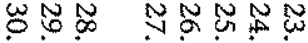

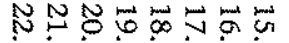

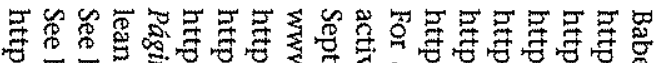

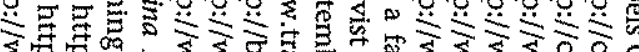

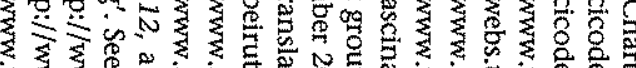

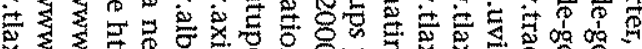

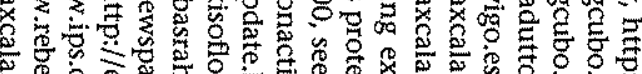

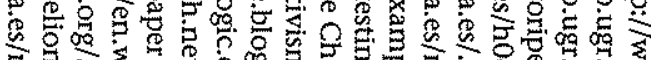

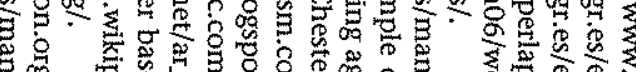

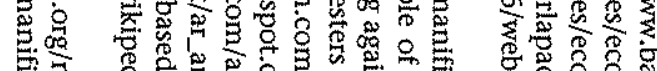


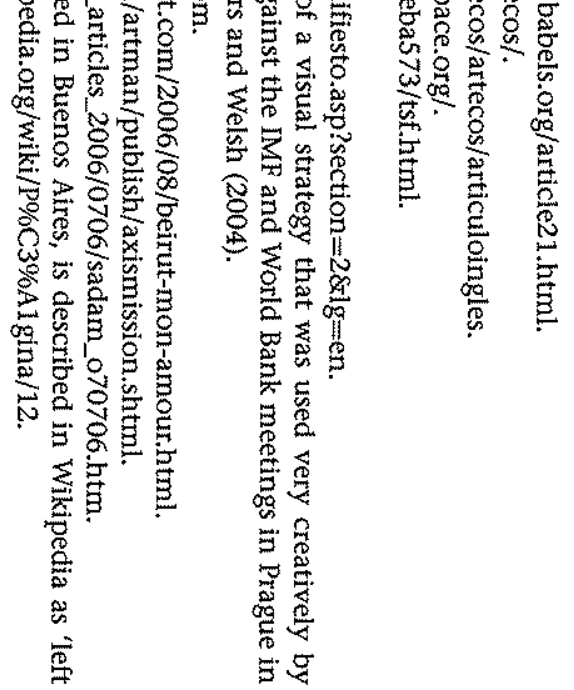

5
5
5
0
0
0
0
0
0 


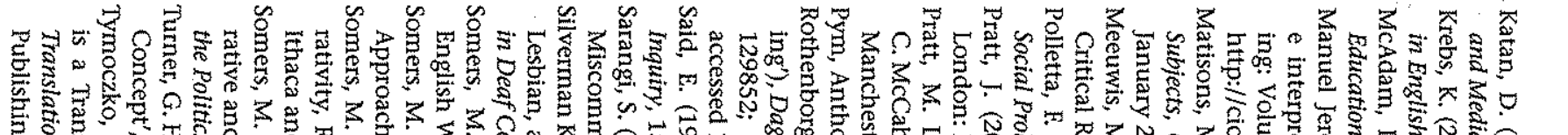

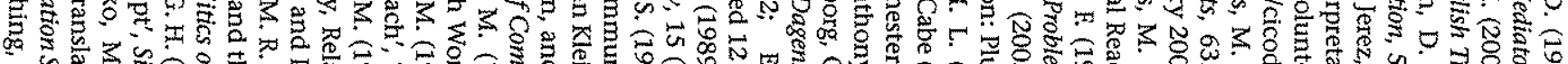

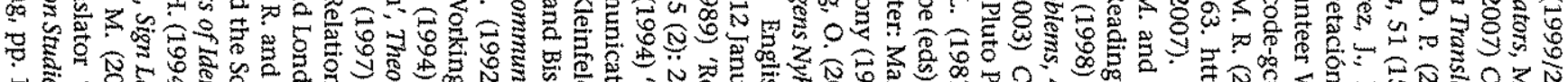

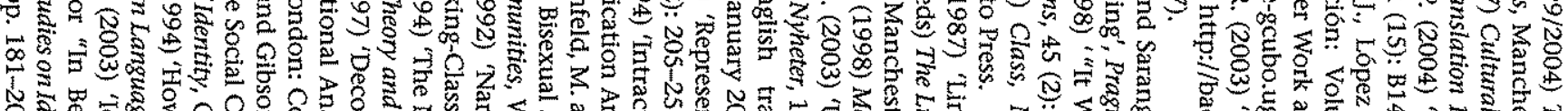

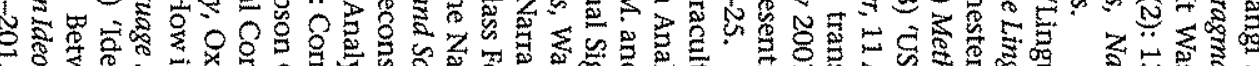

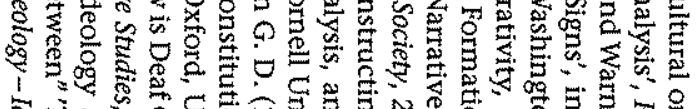

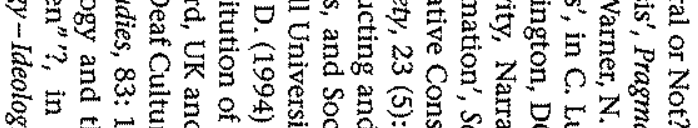

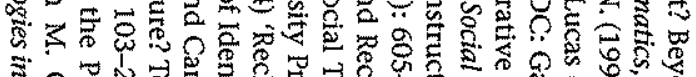

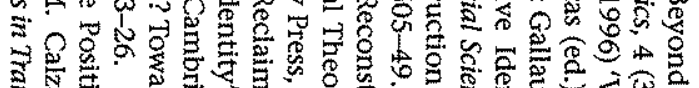

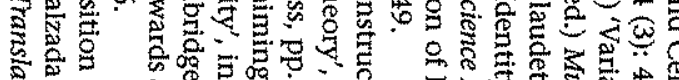

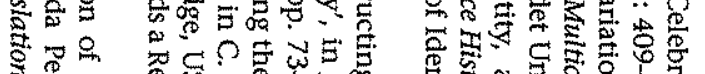

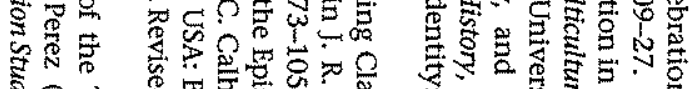

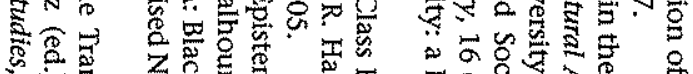

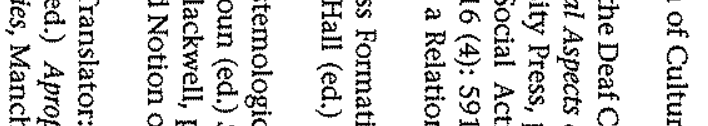

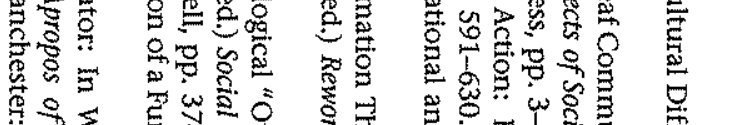

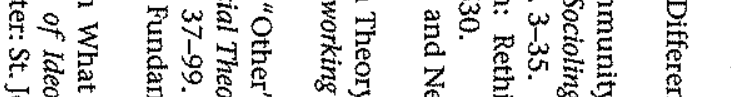

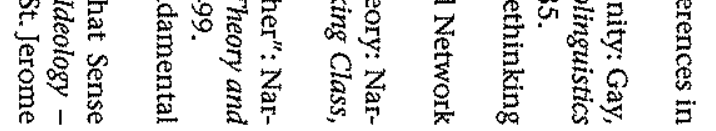

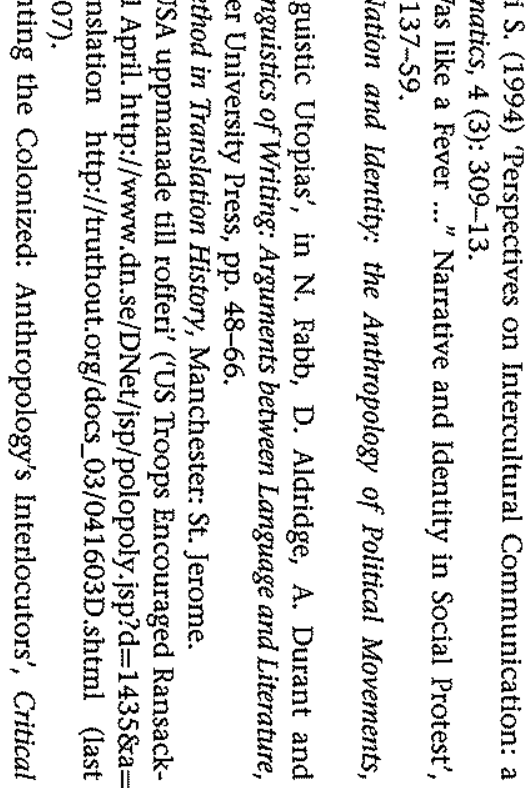

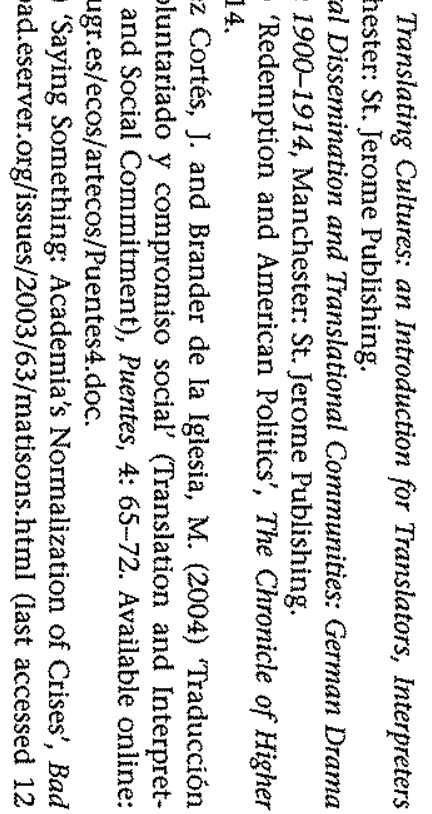

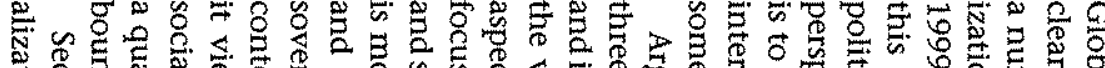

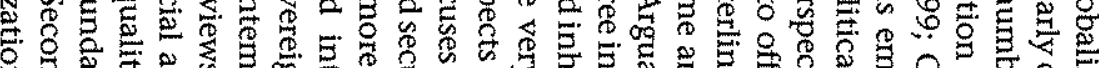

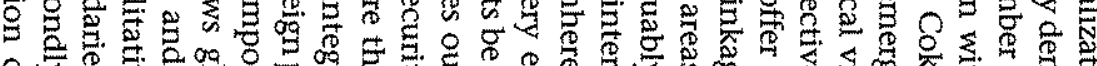

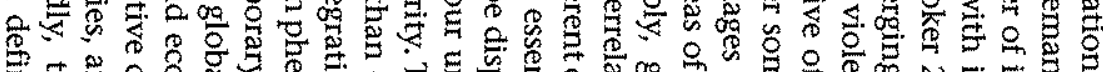

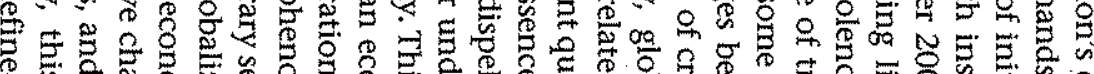

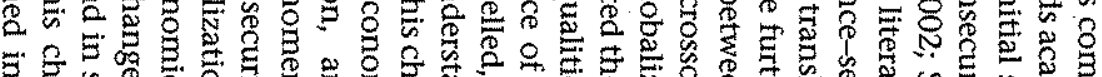

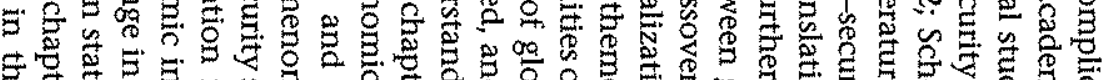

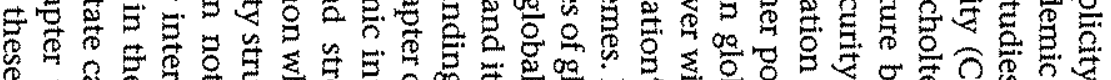

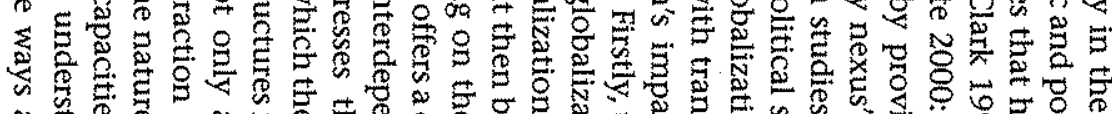

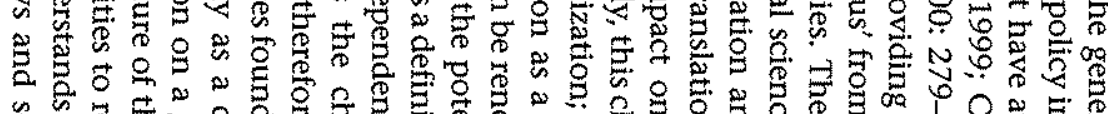

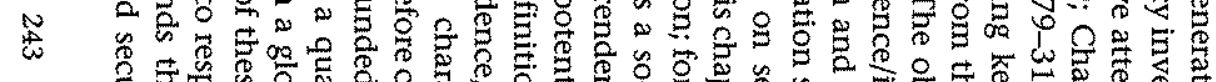

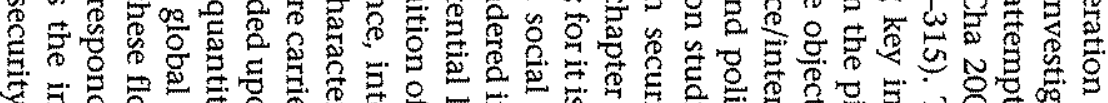

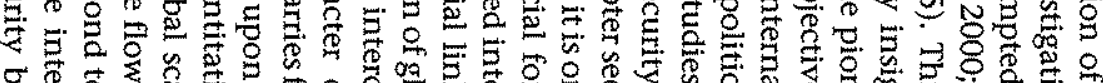

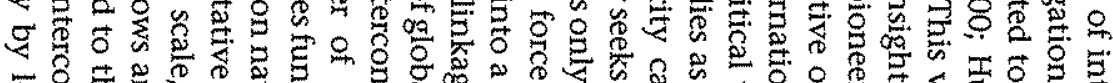

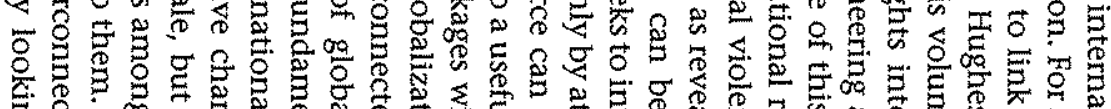

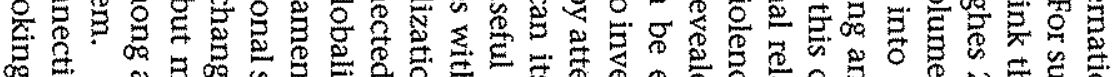

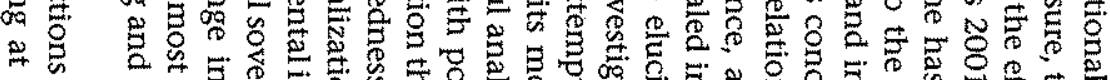

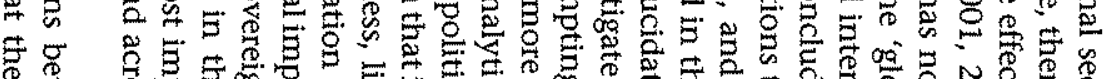

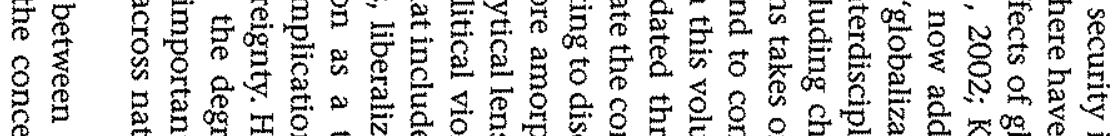

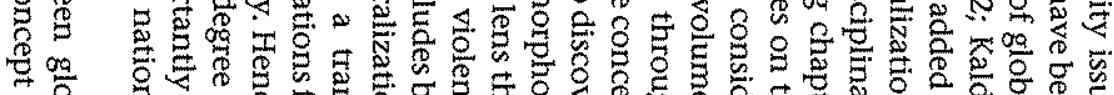

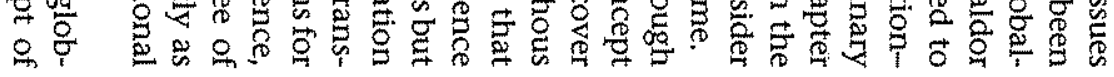

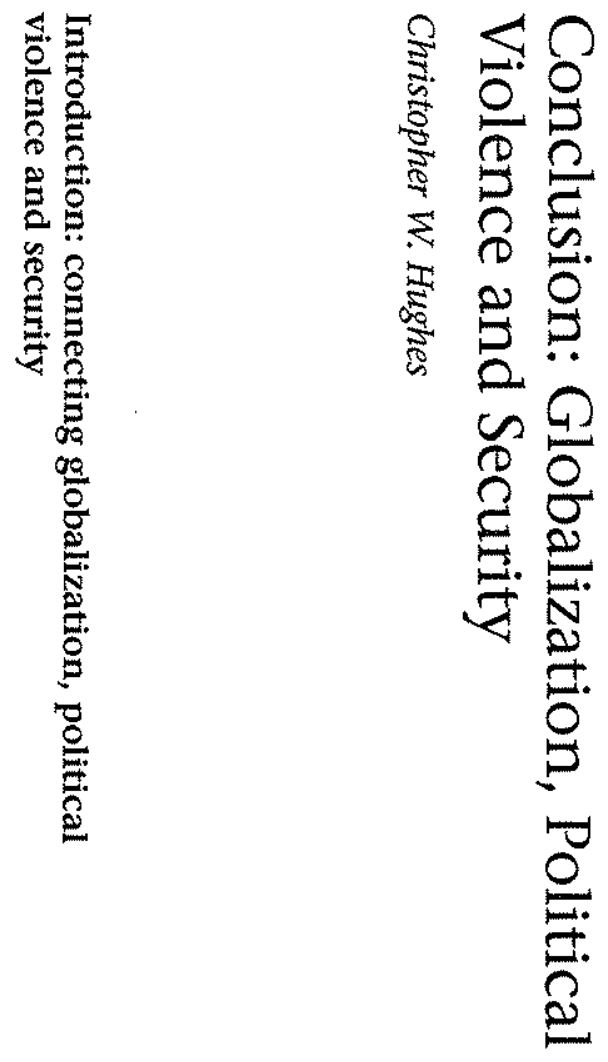

